\title{
34. COMPARISON OF EXPERIMENTALLY CRYSTALLIZED AND NATURAL SPINELS FROM LEG $135^{1}$
}

\author{
L.M. Forsythe ${ }^{2}$ and M.R. Fisk ${ }^{3}$
}

\begin{abstract}
Spinel synthesis experiments performed on samples from Ocean Drilling Program Leg 135 provide constraints for the formation of naturally occurring spinels in these rocks. We evaluated the effect of temperature, $\mathrm{fO}_{2}$, and magma composition on the $\mathrm{Cr} \#$ and $\mathrm{Mg} \#$ of spinel synthesized at a pressure of $1 \mathrm{~atm}$. The experimental evidence suggests that the spinels from Hole 839B must have crystallized above $1200^{\circ} \mathrm{C}$ to produce $\mathrm{Mg \# s}$ of 0.70 to 0.75 (cores) and $\mathrm{Cr} \# \mathrm{~s}$ of 0.74 to 0.76 . Core-to-rim decreases in the $\mathrm{Mg} \#$ but not in the $\mathrm{Cr} \#$ of the natural spinels were not reproduced in equilibrium experiments and reflect disequilibrium reactions in the rocks. This zoning implies that the spinel cores grew from a parent magma that had lower $\mathrm{Al}_{2} \mathrm{O}_{3}$ but similar $\mathrm{Mg \#}$ to the host rock and that mixing of the parent and an evolved magma occurred shortly before eruption. We calculated a reaction constant $\left(\mathrm{K}_{1}\right)$ involving $\mathrm{Al}$ and $\mathrm{Cr}$ exchange between $\mathrm{Mg}$-rich spinel and liquid that is dependent on temperature and fO $\mathrm{O}_{2}$, which enables us to predict the Cr\#s of the liquid in equilibrium with a given spinel composition.
\end{abstract}

\section{INTRODUCTION}

Oxide minerals may indicate the temperature and pressure of their formation in a magma, the chemical composition and oxidation state of their host magma, and the processes affecting these magmas (Hill and Roeder, 1974; Fisk and Bence, 1980; Dick and Bullen, 1984; Allan et al., 1988; Anderson et al., 1991; Roeder and Reynolds, 1991; Allan, 1992). In basaltic magmas, the oxide minerals rich in $\mathrm{Cr}$ and $\mathrm{Al}$ (spinels) are particularly useful indicators because they crystallize at high temperatures and usually are present in trace amounts; thus, they have little impact on the major elements in the host magma (Irvine, 1965, 1967; Thy, 1983; Barnes, 1986; Barsdell, 1988). The effect of magma chemistry, temperature, and pressure on spinel chemistry is calibrated by experimentally synthesizing spinels at a variety of conditions from a variety of basalts.

Most experimental data for spinels in basalts are for tholeiites from mid-ocean ridges (Hill and Roeder, 1974; Fisk and Bence, 1980; Roeder and Reynolds, 1991), alkalic rocks, or continental arc basalts (Sack, 1982); few studies have been done on rocks from ocean arcs or backarc basins. Primitive, spinel-bearing, arc-like basalts with high $\mathrm{Mg}, \mathrm{Cr}$, and $\mathrm{Ni}$ from Hole 839B and more normal backarc basin basalts with some spinel from Hole 834B on Leg 135 (Parson, Hawkins, Allan, et al., 1992) provide an opportunity to explore spinels as petrogenetic indicators in this arc/backarc environment.

This study is an attempt to understand the relationship between spinel composition and oxygen fugacity, temperature, and composition of the basalts from two sites in the Lau Basin. We synthesized spinels in these basalts at temperatures of $1150^{\circ}$ to $1350^{\circ} \mathrm{C}$ and at oxidizing and reducing conditions. To determine the effect of magma composition on spinel composition, we have also synthesized spinel from one of the basalts (839) to which was added either $\mathrm{Mg}$ or Al.

\section{TERMS AND SAMPLE DESCRIPTIONS}

The oxide minerals that are found in Sites 834 and 839 have $\mathrm{Mg}$ greater than $\mathrm{Fe}$ and high $\mathrm{Al}$ and high $\mathrm{Cr}$ abundances (Allan, this volume). Those from Site 834 have more $\mathrm{Al}$ than $\mathrm{Cr}$ and low $\mathrm{Fe}^{3+}$

\footnotetext{
'Hawkins, J., Parson, L., Allan, J., et al., 1994. Proc, ODP, Sci. Results, 135: College Station, TX (Ocean Drilling Program).

${ }^{2}$ Department of Geosciences, Oregon State University, Corvallis, OR 97331-5506, U.S.A.

College of Oceanic and Atmospheric Sciences, Oregon State University, Corvallis, OR 97331-5503, U.S.A.
}

abundances and would be termed "magnesiochromites" (Sigurdsson and Schilling, 1976), and those from Site 839 have more $\mathrm{Cr}$ than $\mathrm{Al}$ and low $\mathrm{Fe}^{3+}$ and would be termed "chromian spinels" (Sigurdsson and Schilling, 1976). For simplicity, however, we refer to oxide minerals from both of these sites as spinels throughout this paper.

Site 834 is $330 \mathrm{~km}$ from the Tofua Arc, and Site 839 is $220 \mathrm{~km}$ from the arc (Parson, Hawkins, Allan, et al., 1992). Table 1 summarizes the chemistry and petrography of the two units from which our samples were selected for experiments. The chemical analyses for Hole 834B Unit 7 and Hole 839B Unit 3 are shipboard X-ray fluorescence (XRF) analyses. The modal abundance data are for thin sections from intervals close to the samples analyzed on board (Parson, Hawkins, Allan, et al., 1992). Because we have studied a single sample from each site, throughout the text we have abbreviated the designation of Sample 135-834B-30R-3, 101-105 cm, to Sample 834 and that of Sample 135-839B-23R-1, 24-27 cm, to Sample 839.

These two starting compositions (Table 1) were selected to be representative of the more $\mathrm{Mg}$-rich compositions from each site. Sample 834 is from about $20 \mathrm{~m}$ above the base of Unit 7, which is about 74 m thick. A thin section taken from Piece 1G (105-107 cm) is a highly phyric plagioclase basalt. It contains $16 \%$ plagioclase and $1 \%$ olivine phenocrysts. Plagioclase grains are up to $3 \mathrm{~mm}$ long. Olivine grains are up to $1.8 \mathrm{~mm}$ in diameter. Spinel is a trace component but is found in plagioclase, olivine, and groundmass. Alteration consists of minor and local replacement of mesostasis with clays (Parson, Hawkins, Allan, et al., 1992).

Chemically, Sample 834 is more similar to Lau Basin backarc basin tholeiites than to the Tonga Arc in that its trace element abundance ratios are intermediate between arc and MORB (Ewart, this volume; Hawkins and Allan, this volume; Parson, Hawkins, Allan, et al., 1992). Spinels from Unit 7 have $\mathrm{Mg}$ numbers $\left[\mathrm{Mg} \# ; \mathrm{Mg}^{2+} / \mathrm{Mg}^{2+}\right.$ $\left.+\mathrm{Fe}^{2+}\right)$ ] that range from 0.56 to 0.72 ; however, in Section 135-834B$30 \mathrm{R}-3$ (from which our sample is derived), the range is 0.66 to 0.68 . The chrome number $\left[\mathrm{Cr} \# ; \mathrm{Cr}^{3+} /\left(\mathrm{Cr}^{3+}+\mathrm{Al}^{3+}\right)\right]$ for Unit 7 spinels ranges from 0.41 to 0.48 , but those from Section 135-834B-30R-3 are uniform at 0.45 (Allan, this volume).

Sample 839 is from about $19.5 \mathrm{~m}$ above the base of the 58 -m-thick Unit 3. The closest thin section to our sample (135-839B-23R-1, $24-26 \mathrm{~cm}$ ) is a highly phyric clinopyroxene olivine basalt. Phenocryst content is $11 \%-17 \%$ and consists primarily of olivine. Olivine phenocrysts are from 0.5 to $3 \mathrm{~mm}$ in diameter. They are euhedral to subhedral and can contain small spinel inclusions up to $0.02 \mathrm{~mm}$. Isolated subhedral spinel crystals also occur up to $0.4 \mathrm{~mm}$ in the groundmass and are darker than those in olivine. Clinopyroxene 
Table 1. Starting compositions for experiments.

\begin{tabular}{|c|c|c|}
\hline Hole: & $834 \mathrm{~B}$ & $839 \mathrm{~B}$ \\
\hline Core, section: & $30 \mathrm{R}-3$ & $23 \mathrm{R}-1$ \\
\hline Interval $(\mathrm{cm})$ : & $101-105$ & $24-27$ \\
\hline Unit: & 7 & 3 \\
\hline Sample label: & 834 & 839 \\
\hline $\mathrm{SiO}_{2}$ & 49.96 & 50.43 \\
\hline $\mathrm{TiO}_{2}$ & 1.25 & 0.59 \\
\hline $\mathrm{Al}_{2} \mathrm{O}_{3}$ & 17.67 & 12.66 \\
\hline $\mathrm{Fe}_{2} \mathrm{O}_{3}$ & 8.99 & 10.36 \\
\hline $\mathrm{MnO}$ & 0.13 & 0.17 \\
\hline $\mathrm{MgO}$ & 7.84 & 14.86 \\
\hline $\mathrm{CaO}$ & 12.15 & 10.92 \\
\hline $\mathrm{Na}_{2} \mathrm{O}$ & 2.59 & 1.21 \\
\hline $\mathrm{K}_{2} \mathrm{O}$ & 0.05 & 0.26 \\
\hline $\mathrm{P}_{2} \mathrm{O}_{5}$ & 0.12 & 0.07 \\
\hline Total & 100.75 & 101.53 \\
\hline LOI & 0.79 & 0.37 \\
\hline \multirow[t]{2}{*}{$\mathrm{Cr}(\mathrm{ppm})$} & 285 & 1740 \\
\hline & \multicolumn{2}{|c|}{ Modal abundances (\% } \\
\hline Interval (cm) & $105-107$ & $24-26$ \\
\hline \multicolumn{3}{|l|}{ Plagioclase: } \\
\hline Phenocryst & 15.7 & - \\
\hline Groundmass & 45.0 & $5-7$ \\
\hline \multicolumn{3}{|l|}{ Clinopyroxene: } \\
\hline Phenocryst & - & $1-2$ \\
\hline Groundmass & 30.0 & $10-15$ \\
\hline \multicolumn{3}{|l|}{ Olivine: } \\
\hline Phenocryst & 0.9 & $10-15$ \\
\hline Groundmass & 2.3 & $3-5$ \\
\hline \multicolumn{3}{|l|}{ Opaques: } \\
\hline Phenocryst & - & - \\
\hline Groundmass & 3.2 & $\operatorname{Tr}$ \\
\hline Mesostasis & 2.7 & 60 \\
\hline Vesicles & 0.2 & $20-25$ \\
\hline
\end{tabular}

Notes: Chemistry is from shipboard analyses by X-ray fluorescence. Chemistry and modal abundances are from Parson, Hawkins, Allan, et al. (1992). LOI $=$ loss on ignition, and $\mathrm{Tr}=$ trace.

occurs as groundmass crystals less than $0.3 \mathrm{~mm}$ long and rarely as subhedral to euhedral, tabular to equant, isolated crystals in glomerocrysts up to $1.2 \mathrm{~mm}$ in length. Some crystals are sector zoned. The unit shows little evidence of alteration.

Sample 839 is chemically similar to primitive island-arc tholeiites by virtue of its $\mathrm{MgO}$ content of almost $15 \mathrm{wt} \%$ and by its trace element signature (Parson, Hawkins, Allan, et al., 1992). The unusually high compatible trace element abundances of $\mathrm{Cr}$ (1740 ppm) and $\mathrm{Ni}(320$ ppm) in Sample 839 suggest accumulation of spinel and olivine. In fact, glass analyses from Unit 3 have nonprimitive compositions $\left(\mathrm{MgO}=7.07, \mathrm{SiO}_{2}=52.14\right)$ (Allan, this volume). The high $\mathrm{Cr}$ and $\mathrm{MgO}$ of this sample relative to the glass does not affect our results other than to increase the range of temperatures over which spinel and olivine crystallize (Hill and Roeder, 1974). Spinels from Sample 839 have a wider range of $\mathrm{Mg} \#(0.50-0.75)$ than those from Sample 834 and higher $\mathrm{Cr} \#$ (around 0.75). Spinels from both Samples 834 and 839 have similar $\mathrm{Fe}^{3+} \#$ of 0.06 to 0.10 (Allan, this volume).

\section{TECHNIQUES}

\section{Sample Preparation}

Whole-rock powders of the two starting compositions were ground to about 80 mesh $(180 \mu \mathrm{m})$. Splits of Sample 839 were mixed with either $3 \mathrm{wt} \% \mathrm{Al}_{2} \mathrm{O}_{3}(839 \mathrm{Al})$ or $3 \mathrm{wt} \% \mathrm{MgCO}_{3}(839 \mathrm{Mg}$ ). (Using $\mathrm{MgCO}_{3}$ rather than $\mathrm{MgO}$ as a source of $\mathrm{Mg}$ does not affect our results because $\mathrm{MgCO}_{3}$ decomposes at about $750^{\circ} \mathrm{C}$ and the $\mathrm{CO}_{2}$ escapes from the sample.) For each experiment, about $0.05 \mathrm{~g}$ of each of the two natural samples (834 and 839) and of the two mixtures (839Al and $839 \mathrm{Mg}$ ) was mixed with polyvinyl alcohol and attached to loops of $0.127-\mathrm{mm}$ Pt wire.

\section{Run Procedure}

Each of the four samples was suspended from a quenchable basket inside a Deltech vertical quench furnace. The temperature of the furnace was raised above $1400^{\circ} \mathrm{C}$ for at least $2 \mathrm{hr}$ to ensure that no crystals remained. Runs at $1400^{\circ} \mathrm{C}$ appeared crystal-free, but the $\mathrm{Cr}$ content of these runs indicate that about $0.5 \mathrm{wt} \%$ spinel could have remained unmelted. The furnace temperature was then lowered to the run temperature for at least 2 days. The temperature was controlled by an external Pt-Pt10Rh thermocouple to within $2^{\circ} \mathrm{C}$, and the interior furnace temperature was monitored by a second $\mathrm{Pt}-\mathrm{Pt} 10 \mathrm{Rh}$ thermocouple suspended inside the furnace with the samples. This thermocouple was calibrated to the melting point of gold at $1064.5^{\circ} \mathrm{C}$. Oxygen fugacity was controlled with a mixture of $\mathrm{CO}_{2}$ and $\mathrm{H}_{2}$ gases. The oxygen fugacity was periodically checked during each run with a Y-stabilized zirconia cell calibrated at the iron-wustite transition at $1300^{\circ} \mathrm{C}$. Oxygen fugacity remained constant during each run within $\pm 0.1 \log$ unit.

Diffusion of Fe from the sample to the platinum loop (Fisk and Bence, 1980; Grove, 1981; Roeder and Reynolds, 1991) was minimized by using the same Pt loop for each composition throughout the experiment. New loops, when needed, were made by melting the starting compositions for $2 \mathrm{hr}$ on the loop. The loop was then quenched and the sample discarded.

At the end of each run, the charges were quenched in distilled water. Part of each sample was examined in transmitted light to determine crystallinity and phases present. Some of each sample was mounted in epoxy, and ground and polished for analysis by microprobe.

\section{Microprobe Procedure}

All analyses were performed on a Cameca SX-50 four-spectrometer microprobe at Oregon State University Electron Microprobe Laboratory. Standards consisted of natural minerals and basalt glass from the Smithsonian reference collection (Jarosewich et al., 1980) and a commercially prepared standard block (Astimex Scientific LTD, 16 Edgewood Crescent, Toronto, Canada, as well as some pure element standards. Measured concentrations were corrected for atomic number, absorption, and fluorescence effects with software provided with the microprobe.

\section{Spinels}

The standards for spinel analyses included Tiebaghi chromite for $\mathrm{Mg}$ and $\mathrm{Cr}$, rutile for Ti, pure V, pyroxmangite for $\mathrm{Mn}$, Minas Gerais magnetite for $\mathrm{Fe}$, synthetic nickel silicate for $\mathrm{Ni}$, and Brazil gahnite for $\mathrm{Zn}$ and $\mathrm{Al}$. $\mathrm{Si}$ and $\mathrm{Na}$ were measured to evaluate beam overlap with glass. Samples were analyzed with an accelerating voltage of 15 $\mathrm{kV}$, a beam current of $50 \mathrm{nA}$, a tightly focused beam, and $10-\mathrm{s}$ counting times for each element. Mn was reduced empirically because of interference of the $\mathrm{Cr} \mathrm{K} \alpha$ and the $\mathrm{Mn} \mathrm{K} \alpha$ peaks, assuming a linear relationship between the $\mathrm{Cr}$ content of the spinel and the magnitude of the $\mathrm{Mn}$ interference. $\mathrm{Fe}^{3+}$ was calculated by normalizing all cations to 3.0 , assuming $\mathrm{Fe}$ was the only multivalent cation, and by partitioning $\mathrm{Fe}$ between $\mathrm{Fe}^{3+}$ and $\mathrm{Fe}^{2+}$ to result in 4.0 oxygens. The precision and accuracy for these elements, based on multiple analyses of Tiebaghi chromite, are reported in Table 2.

\section{Glasses}

Glasses coexisting with chromites were analyzed using the following standards: Makaopuhi basalt glass for $\mathrm{Si}, \mathrm{Ti}, \mathrm{Al}, \mathrm{Fe}$, and $\mathrm{Ca}$; Kakanui anorthoclase for $\mathrm{Na}$; Kakanui augite for $\mathrm{Mg}$; Durango fluorapatite for $\mathrm{P}$; Hohenfels sanidine for $\mathrm{K}$; pyroxmangite for $\mathrm{Mn}$; and Tiebaghi chromite for $\mathrm{Cr}$. Analytical conditions were $15-\mathrm{kV}$ accelerating voltage, $50-\mathrm{nA}$ beam current, defocused beam (approximately 30 $\mu \mathrm{m})$, and 10-s counting times for all elements except $\mathrm{Cr}$, which was 
Table 2. Analytical precision for multiple analyses of standards.

\begin{tabular}{|c|c|c|c|}
\hline & Average & SD & Reported \\
\hline \multicolumn{4}{|c|}{ Tiebaghi chromite: } \\
\hline $\mathrm{SiO}_{2}$ & 0.07 & 0.01 & NR \\
\hline $\mathrm{TiO}_{2}^{2}$ & 0.12 & 0.02 & NR \\
\hline $\mathrm{Al}_{2} \mathrm{O}_{3}$ & 9.96 & 0.16 & 9.92 \\
\hline $\mathrm{Cr}_{2} \mathrm{O}_{3}$ & 59.92 & 0.34 & 60.50 \\
\hline $\mathrm{Fe}_{2} \mathrm{O}_{3}$ & 3.66 & 0.46 & NR \\
\hline $\mathrm{FeO}^{\circ}$ & 9.56 & 0.45 & 13.04 \\
\hline $\mathrm{MnO}$ & 0.17 & 0.02 & 0.11 \\
\hline $\mathrm{MgO}$ & 15.52 & 0.29 & 15.20 \\
\hline $\mathrm{ZnO}$ & 0.06 & 0.03 & NR \\
\hline $\mathrm{NiO}$ & 0.17 & 0.02 & NR \\
\hline $\mathrm{V}_{2} \mathrm{O}_{5}$ & 0.10 & 0.02 & NR \\
\hline $\mathrm{Na}_{2} \mathrm{O}$ & 0.01 & 0.01 & NR \\
\hline Total & 99.31 & & 98.77 \\
\hline & $N=62$ & & \\
\hline \multicolumn{4}{|c|}{ Makaopuhi glass: } \\
\hline $\mathrm{SiO}_{2}$ & 50.60 & 0.15 & 50.94 \\
\hline $\mathrm{TiO}_{2}^{2}$ & 4.05 & 0.02 & 4.06 \\
\hline $\mathrm{Al}_{2} \mathrm{O}_{3}$ & 12.39 & 0.05 & 12.49 \\
\hline $\mathrm{FeO}$ & 13.28 & 0.17 & 13.30 \\
\hline $\mathrm{MnO}$ & 0.20 & 0.01 & 0.15 \\
\hline $\mathrm{MgO}$ & 5.03 & 0.05 & 5.08 \\
\hline $\mathrm{CaO}$ & 8.89 & 0.05 & 9.30 \\
\hline $\mathrm{Na}_{2} \mathrm{O}$ & 2.61 & 0.16 & 2.66 \\
\hline $\mathrm{K}, \mathrm{O}$ & 0.85 & 0.01 & 0.82 \\
\hline $\mathrm{P}_{2} \mathrm{O}_{5}$ & 0.46 & 0.04 & 0.38 \\
\hline Total & 98.36 & & 99.18 \\
\hline $\mathrm{Cr}(\mathrm{ppm})$ & $\begin{array}{l}45 \\
N=7\end{array}$ & 11 & NR \\
\hline
\end{tabular}

Notes: $\mathrm{SD}=$ one standard deviation, $\mathrm{NR}=$ not reported, and $N=$ number of analyses. Where $\mathrm{Fe}_{2} \mathrm{O}_{3}$ is not reported. $\mathrm{FeO}$ is total iron. Reported values are from Jarosewich et al. (1980) for Tiebaghi chromite, USNM 117075, and Makaopuhi glass, USNM 113498/1 VG-A99.

counted for $500 \mathrm{~s}$. Na was always analyzed first and was not significantly different from analyses made with 30 -nA beam current. Precision for these elements is reported in Table 2, based on multiple analyses of the Makaopuhi basalt glass.

One of the goals of this study was to obtain precise $\mathrm{Cr}$ values for the experimental glasses, which have usually not been reported in previous studies of undoped natural compositions. Homogeneous natural glasses with $\mathrm{Cr}$ abundances determined by XRF were provided to us by S. Delong. The $\mathrm{Cr}$ contents (by XRF) of these glasses ranged from 39 to $296 \mathrm{ppm}$, which has been compared to our microprobe analyses in Figure 1. Linear regression of this data produces a line with a slope of $1.03 \pm 0.02(1 \sigma)$ and a $y$-axis intercept of $-15 \pm 10 \mathrm{ppm}(1 \sigma)$.

The similarity of the XRF and microprobe data indicates that no secondary correction is needed for probe analyses between 40 and 300 $\mathrm{ppm} \mathrm{Cr}$. The extension of the regression line passes through our $\mathrm{Cr}$-augite standard at $5800 \mathrm{ppm} \mathrm{Cr}$, which indicates that our probe analyses of 300 to $1260 \mathrm{ppm} \mathrm{Cr}$ also do not need to be corrected. Below $200 \mathrm{ppm} \mathrm{Cr}$, the percent standard deviation of the microprobe analyses is greater than $\pm 10 \%$. From 200 to $300 \mathrm{ppm} \mathrm{Cr}$, however, our precision is better than $10 \%$. All but two of our experimental glasses have more than $200 \mathrm{ppm} \mathrm{Cr}$, so we expect $\mathrm{Cr}$ precision to be better than $10 \%$.

\section{Sources of Error}

Spinels synthesized in basalts are often less than $2 \mu \mathrm{m}$ which makes them difficult to analyze by microprobe (Roeder and Reynolds, 1991). This was also a problem in our experiments. In addition, some spinels in our runs contained glass inclusions, making analyses even more difficult. For this reason, almost all of the spinel grains were located under the beam while observing the rate meter for $\mathrm{Si} K \alpha$. The beam was assumed to be centered on the grain when X-ray intensities for $\mathrm{Si}$ $\mathrm{K} \alpha$ were similar to the $\mathrm{Si}$ background values. Analyses containing more than $1 \mathrm{wt} \% \mathrm{SiO}_{2}$ or totaling less than $98 \mathrm{wt} \%$ were discarded.

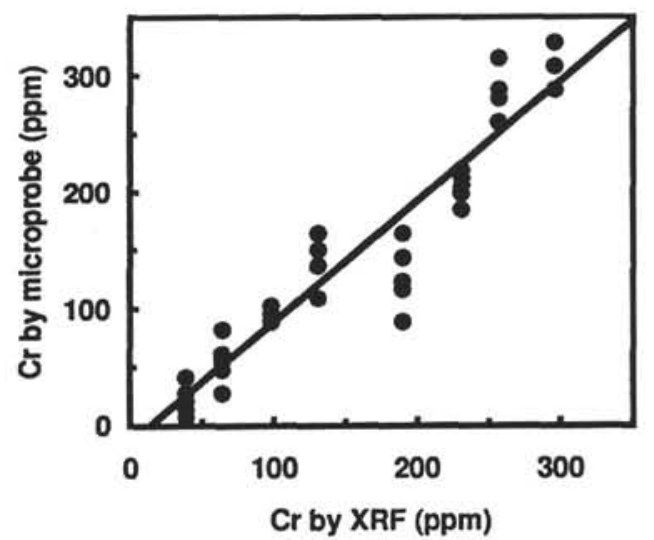

Figure 1. Reported values for glass Cr standards by XRF (S. Delong, pers. comm., 1991) and the values obtained by our microprobe. The line is a linear regression fit to all the data. Standard deviations are discussed in the Methods section.

Other potential problems in experimental work of this type are the loss of volatile elements from the sample to the furnace chamber and loss of Fe from the sample to the Pt loop. Although our glasses have $1 \mathrm{wt} \%$ or less (absolute) variation in $\mathrm{Na}$ for all glasses, we do not consider this to be significant in this study because of the low concentration of $\mathrm{Na}$ in the starting compositions and its incompatibility in the liquidus mineral phases.

The expected iron loss to the Pt wire loop can be estimated from the temperature and $\mathrm{fO}_{2}$ of the experiment as well as the sample mass and the volume of interaction of the sample and the Pt loop (Grove, 1981). Our sample size and $\mathrm{Pt}$ wire were chosen to minimize Fe loss (minimum sample size of about $0.01 \mathrm{~g}$ and $\mathrm{Pt}$ wire diameter of 0.12 $\mathrm{mm}$ ); however, some runs suffered more iron loss than expected, possibly because of a smaller than planned sample size. This does not present a serious problem for our study. The effect of iron loss from an experiment is to increase the $\mathrm{Mg \#}$ of the melt, resulting in higher $\mathrm{Mg} \#$ of the equilibrium spinel than would be expected for the starting composition. Therefore, a comparison of Mg\#s of natural and synthetic spinels must be done with caution; however, because the equilibrium constant we determine is applicable to spinels and melts independent of their Fe contents, the iron loss from our charges does not affect our conclusions.

\section{RESULTS}

\section{Spinel Occurrence}

The experimental conditions and run products are presented in Table 3. Phase boundaries for 839Al experiments (experiments for which we had the greatest percentage of success) are summarized in Figure 2. Differences between this phase diagram and those for 839 and $839 \mathrm{Mg}$ are minor and consistent with the differences in the major element chemistry of the starting compositions. Although spinel was not observed in our $1400^{\circ} \mathrm{C}$ experiments run at quartz-fayalitemagnetite $(\mathrm{QFM}) \mathrm{fO}_{2}$ buffer, we have inferred the spinel liquidus above $1400^{\circ} \mathrm{C}$ by the low $\mathrm{Cr}$ abundance of the glass (about $500 \mathrm{ppm}$ ), compared with the $\mathrm{Cr}$ abundance in the starting composition (about $1700 \mathrm{ppm})$. The $\mathrm{Cr}$ level in the glass can be explained by the presence of $<0.5 \mathrm{wt} \%$ spinel, an amount that could have escaped detection. Olivine joins spinel on the liquidus above $1300^{\circ} \mathrm{C}$, and these two phases crystallize together down to below $1200^{\circ} \mathrm{C}$. Plagioclase was expected in the lower temperature runs, but it was not observed, probably because of delayed nucleation caused by the initial fusion at $1450^{\circ} \mathrm{C}$ (Lofgren and Donaldson, 1975).

No spinels were found in runs at any temperature at 2 log units below QFM except in the $839 \mathrm{Al}$ composition at $1200^{\circ} \mathrm{C}$. Other 
Table 3. Experimental conditions and run products.

\begin{tabular}{|c|c|c|c|c|c|c|c|c|c|c|}
\hline Sample & $\begin{array}{l}\text { Run } \\
\text { no. }\end{array}$ & $\begin{array}{c}\text { Temperature } \\
\left({ }^{\circ} \mathrm{C}\right)\end{array}$ & $\begin{array}{l}\text { Run } \\
\mathrm{fO}_{2}\end{array}$ & $\begin{array}{c}\text { Duration } \\
\text { (hr) }\end{array}$ & Glass & Spinel & Olivine & Clinopyroxene & Orthopyroxene & Plagioclase \\
\hline 834 & R17 & 1153 & $\mathrm{OFM}+2$ & 57 & A & A & P & A & & \\
\hline 834 & R10 & 1201 & $\mathrm{QFM}-2$ & 48 & $\mathrm{P}$ & & & & & \\
\hline 834 & R15 & 1260 & QFM & 62 & P & & & & & \\
\hline 834 & R8 & 1300 & QFM-2 & 63 & & & & & & \\
\hline 834 & R11 & 1300 & QFM & 66 & $P$ & P? & P? & & & \\
\hline 834 & R6 & 1300 & $\mathrm{QFM}+2$ & 56 & $\mathrm{P}$ & P? & $\mathrm{P}$ & & & \\
\hline 834 & R13 & 1400 & QFM & 62 & P & & & & & \\
\hline 839 & R17 & 1153 & $\mathrm{QFM}+2$ & 57 & A & A & A & A & & P? \\
\hline 839 & R16 & 1164 & $\mathrm{QFM}$ & 51 & $\mathrm{P}$ & $\mathrm{P}$ & A & A & & \\
\hline 839 & R10 & 1201 & QFM-2 & 48 & $\mathrm{P}$ & & P & & & \\
\hline 839 & R7 & 1201 & $\mathrm{OFM}+2$ & 48 & A & A & P? & & & \\
\hline 839 & R15 & 1260 & QFM & 62 & P & ${ }_{\mathrm{P}}^{A}$ & A & & & \\
\hline 839 & R5 & 1298 & QFM & 15 & $\mathrm{P}$ & $\mathrm{P}$ & $\mathrm{P}$ & & & \\
\hline 839 & R8 & 1300 & QFM-2 & 63 & P & & P & & & \\
\hline 839 & R11 & 1300 & QFM & 66 & $\mathrm{P}$ & P? & $\mathrm{P}$ & & & \\
\hline 839 & R6 & 1300 & $\mathrm{QFM}+2$ & 56 & P & P? & P & & & \\
\hline 839 & R13 & 1400 & QFM & 62 & $\mathrm{P}$ & & & & & \\
\hline $839 \mathrm{Al}$ & R17 & 1153 & $\mathrm{QFM}+2$ & 57 & P & P & $P$ & A & A & P? \\
\hline $839 \mathrm{Al}$ & R16 & 1164 & QFM & 51 & P & P & A & A & & \\
\hline $839 \mathrm{Al}$ & R10 & 1201 & QFM-2 & 48 & A & A & $\mathrm{P}$ & & & \\
\hline $839 \mathrm{Al}$ & R7 & 1201 & $\mathrm{QFM}+2$ & 48 & $\hat{A}$ & A & $\mathrm{P}$ & & & \\
\hline $839 \mathrm{Al}$ & R15 & 1260 & $\mathrm{QFM}$ & 62 & $\mathrm{P}$ & $\mathrm{p}$ & A & & & \\
\hline $839 \mathrm{Al}$ & R5 & 1298 & QFM & 15 & A & A & P? & & & \\
\hline $839 \mathrm{Al}$ & R8 & 1300 & QFM-2 & 63 & $\mathrm{P}$ & & & & & \\
\hline $839 \mathrm{Al}$ & R11 & 1300 & $\mathrm{QFM}$ & 66 & A & A & P? & & & \\
\hline $839 \mathrm{Al}$ & R6 & 1300 & $\mathrm{QFM}+2$ & 56 & P & $\ddot{\mathrm{P}}$ & $\mathrm{P}$ & & & \\
\hline $839 \mathrm{Al}$ & $\mathrm{R} 13$ & 1400 & $\mathrm{QFM}$ & 62 & P & I & & & & \\
\hline $839 \mathrm{Al}$ & R9 & 1400 & QFM-2 & 60 & P & & & & & \\
\hline $839 \mathrm{Mg}$ & R17 & 1153 & $\mathrm{QFM}+2$ & 57 & P & P & A & & & P? \\
\hline $839 \mathrm{Mg}$ & R16 & 1164 & QFM & 51 & $\mathrm{~A}$ & A & A & A & & \\
\hline $839 \mathrm{Mg}$ & R10 & 1201 & QFM-2 & 48 & P & & P & & & \\
\hline $839 \mathrm{Mg}$ & R7 & 1201 & $\mathrm{QFM}+2$ & 48 & A & P & $\mathrm{P}$ & & & \\
\hline $839 \mathrm{Mg}$ & R15 & 1260 & QFM & 62 & A & A & A & & & \\
\hline $839 \mathrm{Mg}$ & R5 & 1298 & QFM & 15 & A & $\mathrm{A}$ & $\mathrm{P}$ & & & \\
\hline $839 \mathrm{Mg}$ & R8 & $\begin{array}{l}1300 \\
1300\end{array}$ & $\mathrm{QFM}-2$ & 63 & P & & $\mathrm{P}$ & & & \\
\hline $839 \mathrm{Mg}$ & R11 & 1300 & QFM & 66 & $\mathrm{P}$ & P & $\mathrm{P}$ & & & \\
\hline $839 \mathrm{Mg}$ & R6 & 1300 & $\mathrm{QFM}+2$ & 56 & A & P & P & & & \\
\hline $839 \mathrm{Mg}$ & R14 & 1400 & $\mathrm{QFM}+2$ & 58 & $\mathrm{P}$ & I & & & & \\
\hline
\end{tabular}

Notes: QFM = quartz-fayalite-magnetite buffer. QFM+2 and QFM-2 indicate experiments 2 log units above and below QFM, respectively. $\mathrm{A}=$ phase analyzed, $\mathrm{I}=$ inferred from chemistry, and $\mathrm{P}=$ phase present. Olivine, clinopyroxene, and orthopyroxene were analyzed in some runs, but those results are not reported here.

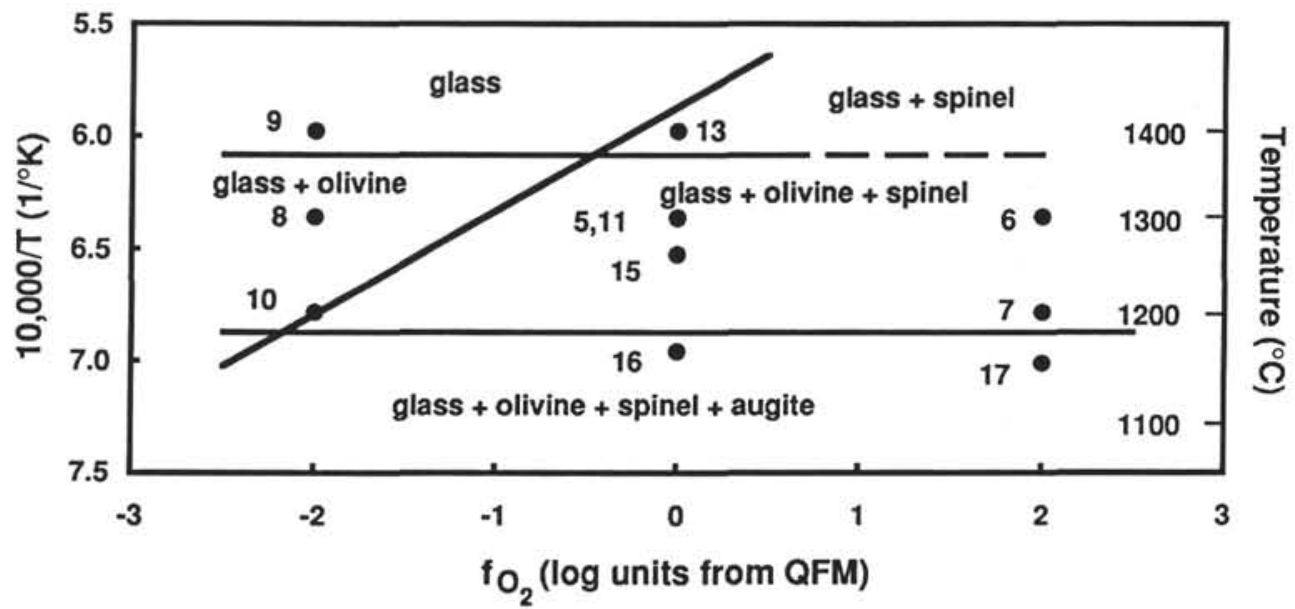

Figure 2. Experimentally determined phase boundaries for Sample 839AI. Run numbers given next to data points. Lines separate fields of various assemblages as marked. Dashed line is the inferred olivine-in line above QFM.

workers have observed this phenomena and attribute it to lower abundances of $\mathrm{Cr}^{3+}$ at lower $\mathrm{fO}_{2}$ (Hill and Roeder, 1974; Fisk and Bence, 1980; Roeder and Reynolds, 1991).

The spinels occur as equant, euhedral to anhedral, brownish yellow grains up to $50 \mu \mathrm{m}$ in diameter, although most fall below $10 \mu \mathrm{m}$. These grains often include substantial areas of glass and are primarily sur- rounded by groundmass or are in contact with olivine grains. Because of the small size of the spinels and their often skeletal nature, only a few core-rim analyses of individual grains could be performed. These data show little or no variation within the grain (Table 4).

Experiments on the natural 834 composition (Table 4) unfortunately produced only one run with spinels large enough to analyze. 
Table 4. Spinel compositions from experimental runs.

\begin{tabular}{|c|c|c|c|c|c|c|c|c|c|c|c|c|c|c|c|c|c|}
\hline Sample & $\begin{array}{l}\text { Run } \\
\text { no. }\end{array}$ & $\mathrm{SiO}_{2}$ & $\mathrm{TiO}_{2}$ & $\mathrm{Al}_{2} \mathrm{O}_{3}$ & $\mathrm{Cr}_{2} \mathrm{O}_{3}$ & $\mathrm{Fe}_{2} \mathrm{O}_{3}$ & $\mathrm{FeO}$ & $\mathrm{MnO}$ & $\mathrm{MgO}$ & $\mathrm{ZnO}$ & $\mathrm{NiO}$ & $\mathrm{V}_{2} \mathrm{O}_{5}$ & $\mathrm{Na}_{2} \mathrm{O}$ & Total & Cr\# & $\mathrm{Fe}^{3+\#}$ & Mg\# \\
\hline 834 & R17 & 0.17 & 0.55 & 41.50 & 13.08 & 15.01 & 12.45 & 0.10 & 17.17 & 0.00 & 0.22 & 0.06 & 0.01 & 100.31 & 0.17 & 0.16 & 0.71 \\
\hline & R7 & .27 & 0.53 & 19.18 & 35.27 & 15.67 & 14.09 & 0.22 & 13.40 & 0.00 & 0.07 & 0.14 & 0.00 & 98.85 & 0.55 & 0.19 & 0.63 \\
\hline 839 & R7 & 0.24 & 0.62 & 19.24 & 34.06 & 16.55 & 14.44 & 0.18 & 13.24 & 0.03 & 0.13 & 0.10 & 0.00 & 98.82 & 0.54 & 0.20 & 0.62 \\
\hline 839 & R17 & 0.34 & 0.58 & 35.71 & 4.02 & 27.65 & 15.64 & 0.15 & 13.89 & & 0.27 & 0.05 & & & 0.07 & & 0.61 \\
\hline $839 \mathrm{Al}$ & R5 & 0.22 & 0.29 & 28.5 & 39.1 & 4.80 & 4.46 & 0.15 & 20. & 0.0 & 0.03 & 0.18 & 0.06 & 98. & 0.48 & 0.05 & 0.89 \\
\hline $839 \mathrm{Al}$ & R7 & 0.58 & 0.43 & 29.38 & 29.01 & 11.87 & 10.22 & 0.27 & 16.85 & 0.00 & 0.08 & 0.08 & 0.01 & 98.78 & 0.40 & 13 & 0.75 \\
\hline $839 \mathrm{Al}$ & R7 & 0.94 & 0.41 & 29.28 & 28.80 & 11.93 & 10.26 & 0.19 & 16.78 & 0.00 & 0.05 & 0.07 & 0.00 & 98.72 & 0.40 & & 0.74 \\
\hline $839 \mathrm{Al}$ & R10 & 42 & 0.21 & 44.05 & 24. & 2.06 & 5.13 & 0.11 & & & & 0. & & & & & 0.88 \\
\hline & R10 & & 0.20 & 43.4 & 25 . & 1.06 & 6.40 & 0.14 & 20.77 & 0.0 & 0.02 & 0.46 & 0.01 & 98. & 0.28 & 0.01 & 0.85 \\
\hline $839 \mathrm{Al}$ & R1O(r) & 0.17 & 0.25 & 37.65 & 31.5 & 1.6 & 6.96 & 0.14 & 19.92 & 0. & 0.02 & 0.63 & 0.01 & 98.87 & 0.36 & 02 & 0.84 \\
\hline $839 \mathrm{Al}$ & R1O(c) & 0.17 & 0.27 & 36. & & & 7.46 & 0.1 & & & & & & & & & 0.82 \\
\hline $839 \mathrm{Al}$ & RI1(r) & 0.11 & & & & & & & & & & & & & & & \\
\hline $839 \mathrm{Al}$ & Ri1( & 0.1 & & & & & 8. & 0. & 18. & & 0.0 & 0.2 & & & 0. & & 0.80 \\
\hline $839 \mathrm{Mg}$ & R5 & 0.27 & 0.21 & 15.7 & 53. & 3.4 & 6.2 & 0. & 17 & & & 0. & & & & & 0.84 \\
\hline $839 \mathrm{~N}$ & R6 & 0.1 & & & & & & & & & & & & & & & 0.88 \\
\hline $839 \mathrm{I}$ & R7 & 0.34 & 0.5 & 19. & 34. & $\begin{array}{r}15.93 \\
\end{array}$ & $\begin{array}{l}14.02 \\
\end{array}$ & 0.2 & & & & 0.1 & & & & & 0.63 \\
\hline $839 \mathrm{Mg}$ & R15 & 0.1 & 0.3 & & & & & & & & & & & & & & 0.82 \\
\hline $839 \mathrm{Mg}$ & R15 & 0.1 & 0.3 & 18. & & & 7. & & & & & & & & & & 0.82 \\
\hline & R15 & & & & & & & & & & & 0.2 & & 98. & 0.65 & & 0.82 \\
\hline & R16 & 0.18 & 0.48 & 20.24 & 43. & 6.25 & $\begin{array}{r}14.0 . \\
\text {. }\end{array}$ & 0.2 & 13. & 0. & 0.00 & 0. & 0.8 & & 0.59 & & 0.63 \\
\hline $839 \mathrm{Mg}$ & R16 & 0.76 & 0.46 & 22.26 & 40.39 & 6.96 & 13.67 & 0.22 & 13.94 & 0.00 & 0.04 & 0.32 & 0.01 & 99.03 & 0.55 & 0.08 & 0.65 \\
\hline
\end{tabular}

Notes: $\mathrm{Fe}_{2} \mathrm{O}_{3}$ calculated according to spinel stoichiometry of three cations and four oxygen atoms. $\mathrm{Cr} \#=\mathrm{Cr} /(\mathrm{Cr}+\mathrm{Al}) ; \mathrm{Fe}^{3+} \#=\mathrm{Fe}^{3+} /\left(\mathrm{Cr}+\mathrm{Al}+\mathrm{Fe}{ }^{3+}\right) ; \mathrm{Mg} \#=\mathrm{Mg} /(\mathrm{Mg}$ $\left.+\mathrm{Fe}^{2+}\right)$; all calculated using cation fractions. $(\mathrm{r})=$ rim analysis, and $(\mathrm{c})=$ core analysis.

This spinel composition is reported along with its coexisting glass and is plotted on some figures for comparison. However, because its composition is more aluminous than the natural spinel found in the 834 sample, we think that our experimental spinel either crystallized at a much lower temperature than the natural spinel, or that it reflects the effect of suppression of plagioclase crystallization in a rock that has accumulated plagioclase (see discussion below).

\section{GENERAL SPINEL CHEMISTRY}

Spinel compositions are often characterized by the variables $\mathrm{Cr} /(\mathrm{Cr}$ $+\mathrm{Al})$ (abbreviated as $\mathrm{Cr} \#)$ and $\mathrm{Mg} /\left(\mathrm{Mg}+\mathrm{Fe}^{2+}\right)(\mathrm{Mg} \#)$ because these parameters describe most of the chemical variation in low- $\mathrm{TiO}_{2}$, low$\mathrm{Fe}^{3+}$ spinels. $\mathrm{Fe}^{3+}$ can substitute for $\mathrm{Al}$ or $\mathrm{Cr}$ in spinels, and some of our diagrams and tables use $\mathrm{Fe}^{3+} /\left(\mathrm{Cr}+\mathrm{Al}+\mathrm{Fe}^{3+}\right)$, hereafter referred to as $\mathrm{Fe}^{3+} \#$ to indicate the magnitude of this $\mathrm{Fe}^{3+}$ substitution. Over the temperature and $\mathrm{fO}_{2}$ range of our experiments, $\mathrm{Cr} \#$ varies dramatically from less than 0.07 to 0.70 (Table 4). Mg\# variation is more restricted and ranges from about 0.61 to about 0.89 and $\mathrm{Fe}^{3+} \#$ ranges from 0.01 to 0.31 .

Equilibrium conditions for the experiments are supported by the similar compositions of spinel grains within single samples (Figs. 3-5). Also, where core and rim compositions were obtained, compositions were uniform with only slight decreases in $\mathrm{Mg} \#$ and $\mathrm{Fe}^{3+} \#$ and increases in $\mathrm{Cr} \#$ from core to rim (Table 4). Spinel grains analyzed from Run 10 do show a greater than expected range in $\mathrm{Cr} \#$, but these do not affect the arguments presented below.

Sample 839, Run 17, has higher $\mathrm{Fe}^{3+}\left(\mathrm{Fe}^{3+} \#=0.31\right)$ than is common for spinels; it also has a much higher $\mathrm{Al}$ content relative to $\mathrm{Cr}$. It is probable that this is a result of the combination of low temperature, high $\mathrm{fO}_{2}$, and higher crystallinity of the charge. The spinels in this charge are commonly enclosed in other phases and may represent compositions controlled by local diffusion (Roeder et al., 1979).

\section{Spinel Cr\#}

The $\mathrm{Cr} \#$ in spinel is determined by several independent factors, as illustrated in Figure 3 . We see that $\mathrm{Cr} \#$ decreases as temperature decreases for the series of $839 \mathrm{Mg}$ runs at QFM and $1298^{\circ}, 1260^{\circ}$, and $1164^{\circ} \mathrm{C}$. Cr\# also decreases as $\mathrm{Al}$ increases in the melt (i.e., Samples $839 \mathrm{Mg}$ and $839 \mathrm{Al}$, Run $\left.7,1200^{\circ} \mathrm{C}, \mathrm{QFM}+2\right)$. ( $\mathrm{Al}$ in the melt also increases as temperature decreases in the $839 \mathrm{Mg}$ series first mentioned.)

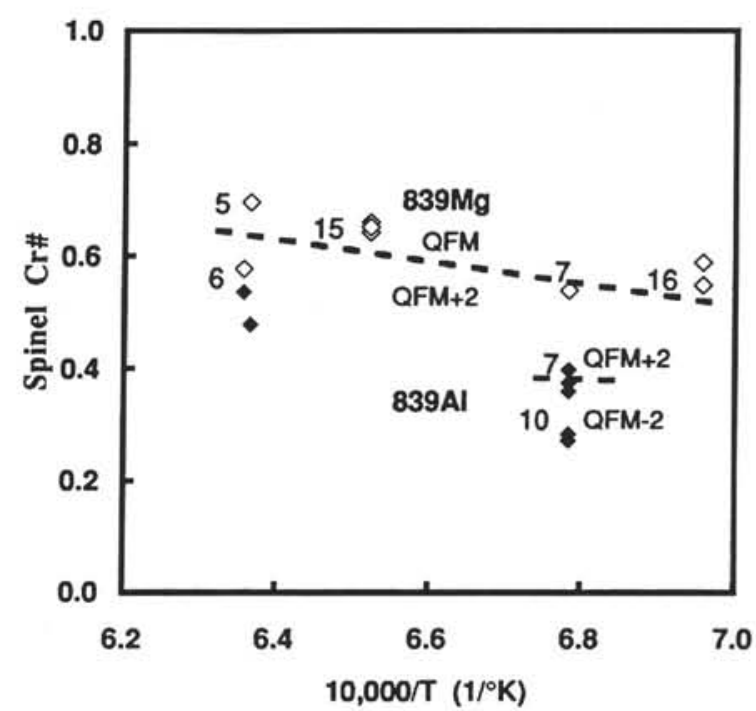

Figure 3. Spinel Cr\# vs. 10,000/T for selected runs of Samples $839 \mathrm{Mg}$ (open diamonds) and 839Al (filled diamonds). Run numbers are indicated next to points, and dashed lines separate data for same sample at different $\mathrm{fO}_{2}$ values.

In addition, $\mathrm{Cr} \#$ may increase or decrease with increasing $\mathrm{fO}_{2}$ as a result of a competing reaction with $\mathrm{Fe}^{3+}$, as discussed in the next section.

These variations in $\mathrm{Cr} \#$ as a function of magma composition, temperature, and oxygen fugacity may be understood in the light of previous experimental studies. Hill and Roeder (1974), Fisk and Bence (1980), and Roeder and Reynolds (1991) observed that the solubility of $\mathrm{Cr}$ in experimental melts depends on temperature and $\mathrm{fO}_{2}$. For a fixed starting composition and $\mathrm{fO}_{2}$, increasing temperature results in increasing $\mathrm{Cr}$ in the melt (e.g., Sample $839 \mathrm{Mg}$, Runs 16 to 15 to 5; Table 5). Following the analogy suggested by Roeder and Reynolds (1991), we attribute this to an increase in the octahedral sites available for $\mathrm{Cr}$ in the melt at higher temperatures. As $\mathrm{fO}_{2}$ decreases for the same composition and temperature (e.g., Sample $839 \mathrm{Al}$, Runs 10 to 7), dissolved $\mathrm{Cr}$ increases in the melt. This is probably because of the reduction of $\mathrm{Cr}^{3+}$ to $\mathrm{Cr}^{2+}$, which has a higher solubility in silicate melts (Hill and Roeder, 1974, Fisk and Bence, 
Table 5. Average compositions, standard deviations, and numbers of measurements of glasses coexisting with spinels.

\begin{tabular}{|c|c|c|c|c|c|c|c|c|c|c|c|c|c|c|c|}
\hline Sample & Run no. & $\mathrm{SiO}_{2}$ & $\mathrm{TiO}_{2}$ & $\mathrm{Al}_{2} \mathrm{O}_{3}$ & $\mathrm{FeOt}$ & $\mathrm{MnO}$ & $\mathrm{MgO}$ & $\mathrm{CaO}$ & $\mathrm{Na}_{2} \mathrm{O}$ & $\mathrm{K}_{2} \mathrm{O}$ & $\mathrm{P}_{2} \mathrm{O}_{5}$ & Total & $\begin{array}{c}\mathrm{Cr} \\
(\mathrm{ppm})\end{array}$ & $\mathrm{FeO}$ & $\mathrm{Fe}_{2} \mathrm{O}_{3}$ \\
\hline 834 & $\begin{array}{l}\mathrm{R} 17 \\
\mathrm{SD}, N=11\end{array}$ & 49.80 & $\begin{array}{l}1.27 \\
0.48\end{array}$ & $\begin{array}{r}18.15 \\
0.03\end{array}$ & $\begin{array}{l}8.74 \\
0.11\end{array}$ & $\begin{array}{l}0.13 \\
0.10\end{array}$ & $\begin{array}{l}6.82 \\
0.02\end{array}$ & $\begin{array}{r}12.15 \\
0.07\end{array}$ & $\begin{array}{l}2.00 \\
0.25\end{array}$ & $\begin{array}{l}0.09 \\
0.05\end{array}$ & $\begin{array}{l}0.03 \\
0.01\end{array}$ & $\begin{array}{r}99.18 \\
0.02\end{array}$ & 48 & $23^{7.83}$ & 1.01 \\
\hline 839 & $\begin{array}{l}\text { R7 } \\
\text { SD, } N=11(5)\end{array}$ & 52.80 & $\begin{array}{l}0.67 \\
1.08\end{array}$ & $\begin{array}{r}15.25 \\
0.02\end{array}$ & $\begin{array}{l}8.68 \\
0.23\end{array}$ & $\begin{array}{l}0.16 \\
0.79\end{array}$ & $\begin{array}{l}8.49 \\
0.03\end{array}$ & $\begin{array}{r}12.33 \\
0.11\end{array}$ & $\begin{array}{l}1.81 \\
0.46\end{array}$ & $\begin{array}{l}0.26 \\
0.07\end{array}$ & $\begin{array}{l}0.03 \\
0.02\end{array}$ & $\begin{array}{r}100.50 \\
0.02\end{array}$ & 298 & $20^{7.67}$ & 1.12 \\
\hline 839 & $\begin{array}{l}\text { R17 } \\
\text { SD, } N=11(5)\end{array}$ & 48.62 & $\begin{array}{l}0.77 \\
0.20\end{array}$ & $\begin{array}{r}16.27 \\
0.04\end{array}$ & $\begin{array}{r}11.78 \\
0.59\end{array}$ & $\begin{array}{l}0.15 \\
0.50\end{array}$ & $\begin{array}{l}7.77 \\
0.03\end{array}$ & $\begin{array}{r}12.20 \\
0.39\end{array}$ & $\begin{array}{l}0.96 \\
0.20\end{array}$ & $\begin{array}{l}0.16 \\
0.05\end{array}$ & $\begin{array}{l}0.03 \\
0.02\end{array}$ & $\begin{array}{r}98.69 \\
0.02\end{array}$ & 193 & $\begin{array}{l}10.7 \\
105\end{array}$ & 1.24 \\
\hline $839 \mathrm{Al}$ & $\begin{array}{l}\text { R5 } \\
\text { SD, } N=10\end{array}$ & 50.64 & $\begin{array}{l}0.60 \\
0.52\end{array}$ & $\begin{array}{r}15.60 \\
0.01\end{array}$ & $\begin{array}{l}6.34 \\
0.41\end{array}$ & $\begin{array}{l}0.18 \\
1.12\end{array}$ & $\begin{array}{r}13.03 \\
0.03\end{array}$ & $\begin{array}{r}10.59 \\
0.11\end{array}$ & $\begin{array}{l}1.67 \\
0.07\end{array}$ & $\begin{array}{l}0.25 \\
0.16\end{array}$ & $\begin{array}{l}0.05 \\
0.05\end{array}$ & $\begin{array}{r}99.10 \\
0.03\end{array}$ & 1000 & $178^{6.11}$ & 0.26 \\
\hline $839 \mathrm{Al}$ & $\begin{array}{l}\text { R7 } \\
\text { SD, } N=15\end{array}$ & 53.69 & $\begin{array}{l}0.86 \\
0.24\end{array}$ & $\begin{array}{r}15.51 \\
0.03\end{array}$ & $\begin{array}{l}6.90 \\
0.10\end{array}$ & $\begin{array}{l}0.19 \\
0.12\end{array}$ & $\begin{array}{l}8.86 \\
0.03\end{array}$ & $\begin{array}{r}12.34 \\
0.13\end{array}$ & $\begin{array}{l}1.83 \\
0.23\end{array}$ & $\begin{array}{l}0.32 \\
0.03\end{array}$ & $\begin{array}{l}0.03 \\
0.01\end{array}$ & $\begin{array}{r}100.54 \\
0.03\end{array}$ & 326 & $\begin{array}{l}6.09 \\
21\end{array}$ & 0.90 \\
\hline $839 \mathrm{Al}$ & $\begin{array}{l}\text { R10 } \\
\text { SD, } N=7(4)\end{array}$ & 51.7 & $\begin{array}{l}0.69 \\
0.23\end{array}$ & $\begin{array}{r}18.87 \\
0.02\end{array}$ & $\begin{array}{l}4.59 \\
0.08\end{array}$ & $\begin{array}{l}0.16 \\
0.18\end{array}$ & $\begin{array}{r}10.33 \\
0.02\end{array}$ & $\begin{array}{r}13.15 \\
0.09\end{array}$ & $\begin{array}{l}0.73 \\
0.35\end{array}$ & $\begin{array}{l}0.16 \\
0.02\end{array}$ & $\begin{array}{l}0.02 \\
0.02\end{array}$ & $\begin{array}{r}100.48 \\
0.02\end{array}$ & 535 & $23^{4.53}$ & 0.06 \\
\hline $839 \mathrm{Al}$ & $\begin{array}{l}\text { R11 } \\
\text { SD, } N=7\end{array}$ & 52.0 & $\begin{array}{l}0.58 \\
0.14\end{array}$ & $\begin{array}{r}15.61 \\
0.01\end{array}$ & $\begin{array}{l}6.27 \\
0.09\end{array}$ & $\begin{array}{l}0.17 \\
0.13\end{array}$ & $\begin{array}{r}14.84 \\
0.03\end{array}$ & $\begin{array}{r}10.83 \\
0.22\end{array}$ & $\begin{array}{l}0.63 \\
0.20\end{array}$ & $\begin{array}{l}0.09 \\
0.02\end{array}$ & $\begin{array}{l}0.05 \\
0.01\end{array}$ & $\begin{array}{r}101.19 \\
0.03\end{array}$ & 981 & $\begin{array}{l}6.07 \\
26\end{array}$ & 0.22 \\
\hline $839 \mathrm{Mg}$ & $\begin{array}{l}\mathrm{R} 5 \\
\mathrm{SD}, N=8\end{array}$ & 53.1 & $\begin{array}{l}0.63 \\
0.61\end{array}$ & $\begin{array}{r}14.24 \\
0.02\end{array}$ & $\begin{array}{l}4.35 \\
0.18\end{array}$ & $\begin{array}{l}0.17 \\
0.21\end{array}$ & $\begin{array}{r}12.90 \\
0.04\end{array}$ & $\begin{array}{r}11.45 \\
0.21\end{array}$ & $\begin{array}{l}1.78 \\
0.15\end{array}$ & $\begin{array}{l}0.27 \\
0.08\end{array}$ & $\begin{array}{l}0.05 \\
0.01\end{array}$ & $\begin{array}{r}99.14 \\
0.03\end{array}$ & 1260 & $133^{4.16}$ & 0.21 \\
\hline $839 \mathrm{Mg}$ & $\begin{array}{l}\text { R6 } \\
\text { SD, } N=5\end{array}$ & 50.4 & $\begin{array}{l}0.57 \\
0.19\end{array}$ & $\begin{array}{r}15.27 \\
0.01\end{array}$ & $\begin{array}{l}7.38 \\
0.08\end{array}$ & $\begin{array}{l}0.18 \\
0.13\end{array}$ & $\begin{array}{r}12.86 \\
0.01\end{array}$ & $\begin{array}{r}10.28 \\
0.10\end{array}$ & $\begin{array}{l}1.56 \\
0.06\end{array}$ & $\begin{array}{l}0.20 \\
0.03\end{array}$ & $\begin{array}{l}0.03 \\
0.01\end{array}$ & $\begin{array}{r}98.85 \\
0.02\end{array}$ & 597 & $\begin{array}{l}6.70 \\
33\end{array}$ & 0.76 \\
\hline $839 \mathrm{Mg}$ & $\begin{array}{l}\text { R7 } \\
\text { SD, } N=7\end{array}$ & 52.5 & $\begin{array}{l}0.70 \\
0.33\end{array}$ & $\begin{array}{r}15.26 \\
0.03\end{array}$ & $\begin{array}{l}8.74 \\
0.08\end{array}$ & $\begin{array}{l}0.15 \\
0.12\end{array}$ & $\begin{array}{l}8.12 \\
0.03\end{array}$ & $\begin{array}{r}13.13 \\
0.05\end{array}$ & $\begin{array}{l}1.79 \\
0.07\end{array}$ & $\begin{array}{l}0.26 \\
0.04\end{array}$ & $\begin{array}{l}0.03 \\
0.01\end{array}$ & $\begin{array}{r}100.70 \\
0.03\end{array}$ & $\mathrm{NA}$ & 7.70 & 1.16 \\
\hline $839 \mathrm{Mg}$ & $\begin{array}{l}\mathrm{R} 15 \\
\mathrm{SD}, N=10(4)\end{array}$ & 54.2 & $\begin{array}{l}0.69 \\
0.83\end{array}$ & $\begin{array}{r}14.74 \\
0.03\end{array}$ & $\begin{array}{l}4.86 \\
0.16\end{array}$ & $\begin{array}{l}0.17 \\
0.18\end{array}$ & $\begin{array}{r}11.45 \\
0.03\end{array}$ & $\begin{array}{r}12.49 \\
0.10\end{array}$ & $\begin{array}{l}1.07 \\
0.19\end{array}$ & $\begin{array}{l}0.23 \\
0.03\end{array}$ & $\begin{array}{l}0.05 \\
0.02\end{array}$ & $\begin{array}{r}100.03 \\
0.02\end{array}$ & 766 & $\begin{array}{l}4.65 \\
14\end{array}$ & 0.22 \\
\hline $839 \mathrm{Mg}$ & $\begin{array}{l}\mathrm{R} 16 \\
\mathrm{SD}, N=11(5)\end{array}$ & 53.4 & $\begin{array}{l}0.75 \\
0.19\end{array}$ & $\begin{array}{r}17.08 \\
0.02\end{array}$ & $\begin{array}{l}7.27 \\
0.38\end{array}$ & $\begin{array}{l}0.15 \\
0.14\end{array}$ & $\begin{array}{l}7.23 \\
0.02\end{array}$ & $\begin{array}{r}12.34 \\
0.09\end{array}$ & $\begin{array}{l}1.46 \\
0.30\end{array}$ & $\begin{array}{l}0.28 \\
0.03\end{array}$ & $\begin{array}{l}0.07 \\
0.01\end{array}$ & $\begin{array}{r}100.09 \\
0.03\end{array}$ & 256 & 14.96 & 0.34 \\
\hline
\end{tabular}

Notes: $\mathrm{FeO}$ and $\mathrm{Fe}_{2} \mathrm{O}_{3}$ are calculated according to Sacket al. (1980). The first number under each column is an average of $N$ analysesin wt\%, with numbers in parentheses indicating where $N$ for the $\mathrm{Cr}$ analyses is different. The second number under each column is the $1 \sigma$ standard deviation. $\mathrm{NA}=$ not analyzed.

1980). For instance, Roeder and Reynolds (1991) suggest that $\mathrm{Cr}^{2+}$ should be about half of all $\mathrm{Cr}$ at $1300^{\circ} \mathrm{C}$ at QFM while falling to 0.1 of all $\mathrm{Cr}$ at $1300^{\circ} \mathrm{C}$ at $\mathrm{QFM}+2$.

Roeder and Reynolds (1991) also suggest Cr solubility is related to melt Fe concentration. Although Fe loss created variable Fe concentrations in some of our runs, this effect on melt $\mathrm{Cr}$ concentration was not specifically evaluated.

\section{Spinel $\mathrm{Fe}^{3+\#}$}

The amount of $\mathrm{Fe}^{3+}$ in spinel should reflect $\mathrm{fO}_{2}$ conditions at equilibrium. However, Ballhaus et al. (1991) point out that redox equilibrium in spinels can be difficult to achieve in reversal experiments. All of our experiments involve synthesis of spinel from liquid that has been above the liquidus, so our spinel redox should reflect equilibrium at run conditions. For one starting composition at QFM, $\mathrm{Fe}^{3+} \#$ in spinel increases only slightly with decreasing temperature (Runs 5 to 15 to 16, Fig. 4). For runs at QFM+2, however, $\mathrm{Fe}^{3+} \#$ rises dramatically as temperature drops (Runs 6 to 7 to 17). This is probably a result of increased $\mathrm{Fe}^{3+}$ in the melt, combined with increasing $\mathrm{Fe}$ in spinel with decreasing temperature. Spinel $\mathrm{Fe}^{3+} \#$, therefore, increases because of the ability of $\mathrm{Fe}^{3+}$ to replace $\mathrm{Cr}^{3+}$ in the spinel structure. Consistent with this logic, spinels in runs at QFM-2 have much lower $\mathrm{Fe}^{3+} \#$ than those at higher $\mathrm{fO}_{2}$.

\section{Spinel Mg\#}

The $\mathrm{Mg} \#$ of a spinel should correlate well with the $\mathrm{Mg} \#$ of the melt because of the rapid exchange of $\mathrm{Mg}$ and $\mathrm{Fe}^{2+}$ (Hill and Roeder, 1974; Fisk and Bence, 1980; Roeder and Reynolds, 1991; Allan, 1992, also in this volume). Furthermore, $\mathrm{Fe}^{2+}$ is the dominant iron species in the melt in the $\mathrm{fO}_{2}$ range of our experiments, so $\mathrm{Mg} \#$ in the melt is not strongly influenced by changes in $\mathrm{fO}_{2}$. Spinel $\mathrm{Mg} \#$, therefore, can be

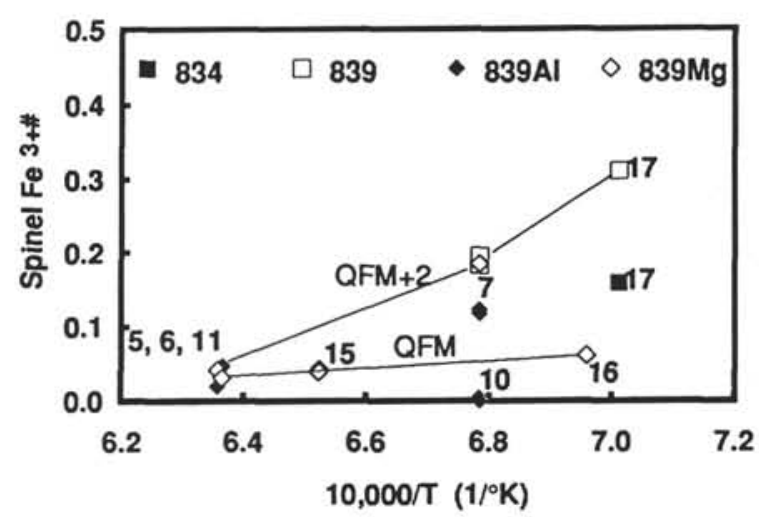

Figure 4. Spinel $\mathrm{Fe}^{3+} \#$ vs. $10,000 / \mathrm{T}$ for all the experiments. Symbols refer to different compositions according to the legend and the numbers are runs. Lines connect experiments of Sample $839 \mathrm{Mg}$ at similar $\mathrm{fO}_{2}$ buffers. (The $\mathrm{QFM}+2$ line was extended to lower temperatures using the undoped composition because these two compositions produced similar spinel compositions.)

used to determine the existence of equilibrium between natural spinels and host glasses. For our experiments, the $\mathrm{Mg} \#$ of the spinel decreases by about the same amount as the Mg\# of the melt for similar compositions and at constant $\mathrm{fO}_{2}$ (Fig. 5), in agreement with previous workers.

\section{DISCUSSION}

The primary aim of this study is to relate spinel composition to temperature, $\mathrm{fO}_{2}$, and the natural melt compositions. An in-depth treatment by Allan of the spinels found in the rocks from Holes 834 and 839 can be found elsewhere in this volume. In general, the spinels 


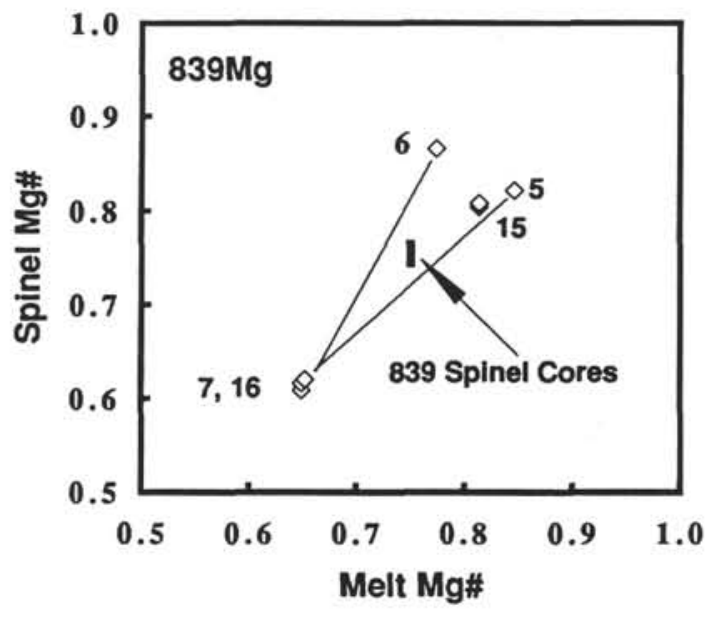

Figure 5. Mg\# of spinels from Sample $839 \mathrm{Mg}$ vs. Mg\# of coexisting melts. Numbers, light lines, and symbols are as in previous figures. Heavy line identified as 839 spinel cores is the approximate range of natural spinel cores analyzed by Allan (this volume) plotted vs. a mid-range $\mathrm{Mg} \#$ value that he calculated for the equilibrium melt.

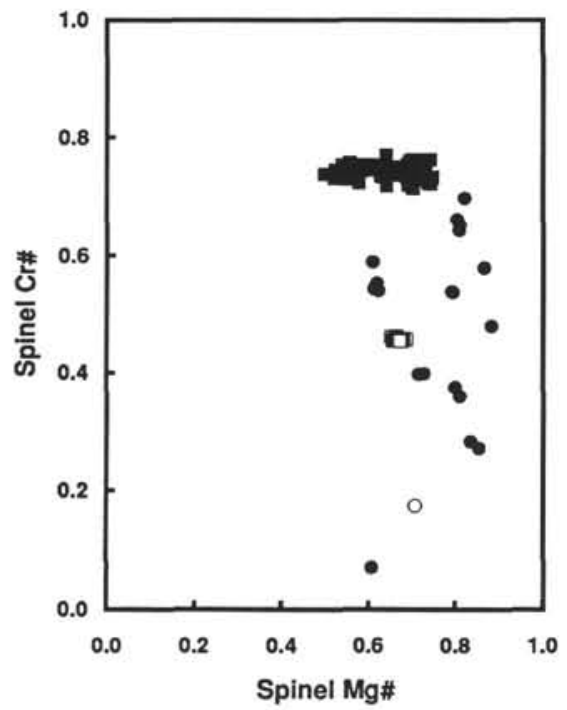

Figure 6. Cr\# vs. Mg\# for spinels from our experiments (filled circles = Samples $839,839 \mathrm{Mg}$, and $839 \mathrm{Al}$; open circle $=$ Sample 834 composition ) and Allan's (this volume) analyses (filled squares $=$ Sample 839 ; open squares = Sample 834).

are euhedral and can be very large (see sample description). Chemically, they exhibit zoning in $\mathrm{Mg} \#$ but little change in $\mathrm{Cr} \#$ from core to rim (Fig. 6). The Mg\# ranges from 0.73 in the cores to 0.55 on the rims; the $\mathrm{Cr} \#$, however, varies little from 0.75 with perhaps a slight increase at the rim. The $\mathrm{Fe}^{3+} \#$ in all spinels is below 0.15 .

Spinel compositions from Samples $839 \mathrm{Mg}$ and 839 are similar when synthesized under identical experimental conditions. The experimental melt and spinel $\mathrm{Mg} \# \mathrm{~s}$ for $839 \mathrm{Mg}$ are compared with natural spinels in Figure 5. Based on the correlation of $\mathrm{Mg \#}$ s of spinel and melt from the experiments, the $\mathrm{Mg \#}$ of the cores in natural spinels suggests a melt $\mathrm{Mg \#}$ of between 0.72 and 0.79 . For the rims, the melt should have a Mg\# of 0.60 . In agreement with this, Allan (this volume) predicts a $\mathrm{Mg} \#$ of melt in equilibrium with the cores to be 0.79 and for rims of about 0.63 . The only glass analysis available from the same unit as our Sample 839 (Allan, this volume) indicates that it is close to equilibrium with the rims ( $\mathrm{Mg \#}$ around 0.63 ). Therefore, based on $\mathrm{Mg \# s}$ for the $\mathrm{Mg}$-doped sample runs, experimental data support the argument that cores formed between $1250^{\circ}$ and $1220^{\circ} \mathrm{C}$ (midway between $839 \mathrm{Mg}$ Runs 15 and 16). Keeping in mind that correcting for $\mathrm{Fe}$-loss from the runs at higher temperatures (Runs 5 and 15) would shift their compositions down the line toward Run 16, the true crystallization temperature is more likely to be near $1250^{\circ} \mathrm{C}$.

In terms of trivalent cations, the absence of experimental spinels with $\mathrm{Cr} \# \mathrm{~s}$ as high as the cores of the natural spinels (Fig. 6) has two important implications. First, we infer that our starting composition has higher $\mathrm{Al}$ than the liquid in equilibrium with the spinel cores because, even in our $1300^{\circ} \mathrm{C}$ runs, the highest $\mathrm{Cr} \#$ is only 0.70 . The high $\mathrm{Al}$ content of the spinel from the one run on a Site 834 sample is probably related to the high plagioclase content of this rock and the suppression of plagioclase crystallization in our experiment. Plagioclase crystallization can be suppressed in experiments when nuclei are destroyed at superliquidus temperatures (Lofgren and Donaldson, 1975). The initial fusion temperature at $>1400^{\circ} \mathrm{C}$ destroyed all plagioclase nuclei in Sample 834. This would result in a dramatically higher $\mathrm{Al}$ content in the glass and a lower relative $\mathrm{Cr}$, which should favor a more aluminous spinel. The glass analyses (Table 4) support this idea.

We also infer that the $\mathrm{Mg} \#$ and $\mathrm{Cr} \#$ characteristic of the spinel rims from Hole 839 Unit 3 are not consistent with equilibrium crystallization. Our data suggest that spinel Mg\#s must covary with Cr\#s and that a spinel with $0.55 \mathrm{Mg} \#$ should also have $\mathrm{a} \mathrm{Cr} \#$ between 0.5 and 0.6 (inferred from Fig. 3 by interpolating between Runs 15 and 16). It is difficult, therefore, to envision how natural spinels with decreasing Mg\#s and constant-to-rising Cr\#s arise from equilibrium magma chamber process.

We next chose to examine the data for temperature influence on spinel composition by the mineral-melt exchange reaction:

$$
\mathrm{MgCr}_{2} \mathrm{O}_{4}(\mathrm{sp})+\mathrm{Al}_{2} \mathrm{O}_{3}(\text { liq })=\mathrm{MgAl}_{2} \mathrm{O}_{4}(\mathrm{sp})+\mathrm{Cr}_{2} \mathrm{O}_{3} \text { (liq) },
$$

for which the equilibrium constant may be written:

$$
\mathrm{K}_{1}=\mathrm{a}(\mathrm{sp}) / \mathrm{a}(\mathrm{Mg}-\mathrm{chr}) \cdot \mathrm{a}\left(\mathrm{Cr}_{2} \mathrm{O}_{3}(\text { liq })\right) / \mathrm{a}\left(\mathrm{Al}_{2} \mathrm{O}_{3}(\text { liq })\right) \text {, }
$$

where $\mathrm{a}(\mathrm{X})$ indicates the activity of component $\mathrm{X}$. This reaction was chosen as being appropriate because the spinels in this study have more $\mathrm{Mg}$ than $\mathrm{Fe}$, and because $\mathrm{Cr}$ and $\mathrm{Al}$ dominate the trivalent cation composition.

Taking into account the nonideal solid solution behavior between the spinel components, we used the activity model derived by Sack and Ghiorso (1991) to calculate the activity of the end-member spinel components (Table 6). As expected, spinel sensu stricto $\left(\mathrm{MgAl}_{2} \mathrm{O}_{4}\right)$ and $\mathrm{Mg}$-chromite $\left(\mathrm{MgCr}_{2} \mathrm{O}_{4}\right)$ components have the highest activities, indicating the significance of the reaction. These components have activities similar to but larger than the $\mathrm{FeAl}_{2} \mathrm{O}_{4}$ and $\mathrm{FeCr}_{2} \mathrm{O}_{4}$ endmembers. The $\mathrm{Ti}$ and $\mathrm{Fe}^{3+}$ end-member spinels have activities almost an order of magnitude lower than the $\mathrm{Mg}-\mathrm{Fe}-\mathrm{Al}-\mathrm{Cr}$ components.

The activities of $\mathrm{Cr}[\mathrm{a}(\mathrm{Cr})]$ and $\mathrm{Al}[\mathrm{a}(\mathrm{Al})]$ in the glass were calculated using the two-lattice melt model of Nielsen and Drake (1979) (Table 7). In this model, the activity of aluminum available for spinel formation is $\mathrm{Al}$ in excess of that combined with $\mathrm{Na}$ and $\mathrm{K}$ in $\mathrm{NaAl}$ and $\mathrm{KAl}$ in the network-former lattice. $\mathrm{Cr}$ activity is equivalent to the cation mole fraction of $\mathrm{Cr}$ relative to the sum of the network modifiers only.

Roeder and Reynolds (1991) point out that the $\mathrm{Cr}^{2+} / \mathrm{Cr}^{3+}$ ratio in the liquid can be as high as 1 in natural silicate liquids at magmatic conditions. We use their empirical relationship to calculate $\mathrm{Cr}^{2+} / \mathrm{Cr}^{3+}$ and the activity of $\mathrm{Cr}^{3+}$ from the total activity of $\mathrm{Cr}$. We then introduce the ratio, $\mathrm{Cr}^{3+} \#=\mathrm{a}\left(\mathrm{Cr}^{3+}\right) /\left[\mathrm{a}(\mathrm{Al})+\mathrm{a}\left(\mathrm{Cr}^{3+}\right)\right]$, or, in other words, the activity of trivalent $\mathrm{Cr}$ in the melt (not the total activity of $\mathrm{Cr}$ ) and the activity of the network modifying $\mathrm{Al}$ (not the total $\mathrm{Al}$ ).

With these activities, we calculated the linear regression for Equation 1 (Fig. 7) from our data. One glass composition in which $\mathrm{Cr}$ was 
Table 6. Activities of spinel components calculated using the model of Sack and Ghiorso (1991).

\begin{tabular}{|c|c|c|c|c|c|c|c|c|c|}
\hline Sample & $\begin{array}{c}\text { Run } \\
\text { no. }\end{array}$ & $\mathrm{a}(\mathrm{hc})$ & $a(s p)$ & a(usp) & $a(m t)$ & $\mathrm{a}(\mathrm{Mg}-\mathrm{Ti})$ & $\mathrm{a}(\mathrm{Mg}-\mathrm{Fe})$ & $a(c h r)$ & $\mathrm{a}(\mathrm{Mg}-\mathrm{chr})$ \\
\hline 834 & $\mathrm{R} 17$ & 0.3126 & 0.3959 & 0.0215 & 0.1285 & 0.0177 & 0.0710 & 0.0367 & 0.0303 \\
\hline 839 & R7 & 0.1803 & 0.2406 & 0.0111 & 0.0677 & 0.0156 & 0.0326 & 0.1377 & 0.1398 \\
\hline 839 & R7 & 0.1839 & 0.2422 & 0.0128 & 0.0752 & 0.0170 & 0.0361 & 0.1313 & 0.1305 \\
\hline 839 & R17 & 0.3391 & 0.3833 & 0.0189 & 0.3095 & 0.0124 & 0.1647 & 0.0040 & 0.0028 \\
\hline $839 \mathrm{Al}$ & R5 & 0.0866 & 0.3154 & 0.0014 & 0.0039 & 0.0191 & 0.0062 & 0.0722 & 0.2310 \\
\hline $839 \mathrm{Al}$ & R7 & 0.2006 & 0.3251 & 0.0087 & 0.0480 & 0.0157 & 0.0313 & 0.0975 & 0.1184 \\
\hline $839 \mathrm{Al}$ & R7 & 0.2008 & 0.3250 & 0.0083 & 0.0492 & 0.0149 & 0.0320 & 0.0969 & 0.1174 \\
\hline $839 \mathrm{Al}$ & R10 & 0.1626 & 0.4434 & 0.0031 & 0.0018 & 0.0149 & 0.0022 & 0.0652 & 0.1314 \\
\hline $839 \mathrm{Al}$ & R10 & 0.2006 & 0.4324 & 0.0045 & 0.0005 & 0.0135 & 0.0005 & 0.0863 & 0.1377 \\
\hline $839 \mathrm{Al}$ & R10 & 0.1844 & 0.3903 & 0.0048 & 0.0011 & 0.0157 & 0.0009 & 0.1090 & 0.1770 \\
\hline $839 \mathrm{Al}$ & R10 & 0.1936 & 0.3808 & 0.0058 & 0.0007 & 0.0166 & 0.0006 & 0.1212 & 0.1838 \\
\hline $839 \mathrm{Al}$ & R11 & 0.1358 & 0.2756 & 0.0025 & 0.0015 & 0.0124 & 0.0013 & 0.1416 & 0.2552 \\
\hline $839 \mathrm{Al}$ & R11 & 0.1377 & 0.2749 & 0.0031 & 0.0014 & 0.0147 & 0.0011 & 0.1441 & 0.2553 \\
\hline $839 \mathrm{Mg}$ & R5 & 0.0652 & 0.1793 & 0.0013 & 0.0018 & 0.0200 & 0.0019 & 0.1414 & 0.3733 \\
\hline $839 \mathrm{Mg}$ & R6 & 0.0762 & 0.2594 & 0.0013 & 0.0027 & 0.0204 & 0.0038 & 0.0940 & 0.2942 \\
\hline $839 \mathrm{Mg}$ & R7 & 0.1836 & 0.2461 & 0.0119 & 0.0703 & 0.0165 & 0.0344 & 0.1322 & 0.1342 \\
\hline $839 \mathrm{Mg}$ & R15 & 0.0863 & 0.2085 & 0.0028 & 0.0029 & 0.0268 & 0.0026 & 0.1506 & 0.3326 \\
\hline $839 \mathrm{Mg}$ & R15 & 0.0902 & 0.2197 & 0.0029 & 0.0035 & 0.0260 & 0.0031 & 0.1441 & 0.3180 \\
\hline $839 \mathrm{Mg}$ & R15 & 0.0854 & 0.2145 & 0.0024 & 0.0031 & 0.0244 & 0.0029 & 0.1433 & 0.3283 \\
\hline $839 \mathrm{Mg}$ & R16 & 0.2075 & 0.2475 & 0.0141 & 0.0139 & 0.0194 & 0.0052 & 0.2258 & 0.2059 \\
\hline $839 \mathrm{Mg}$ & R16 & 0.2163 & 0.2670 & 0.0136 & 0.0181 & 0.0180 & 0.0073 & 0.2017 & 0.1885 \\
\hline
\end{tabular}

Notes: $\mathrm{a}(\mathrm{X})=$ activity of spinel component $\mathrm{X}$ in spinel calculated from Table 4 according to the model of Sack and Ghiorso (1991). hc = hercynite, $\mathrm{sp}=$ spinel, $\mathrm{usp}=$ ulvo-spinel, $\mathrm{mt}=$ magnetite, $\mathrm{Mg}-\mathrm{Ti}=$ magnesium-titanium spinels, and $\mathrm{Mg}-\mathrm{Fe}=$ magnesium-iron spinels.

Table 7. Activities of glass components based on the Nielsen and Drake (1979) modification of Bottinga and Weill's (1972) two-lattice melt model.

\begin{tabular}{|c|c|c|c|c|c|c|c|c|c|c|c|c|}
\hline \multirow[b]{2}{*}{ Sample } & \multirow[b]{2}{*}{$\begin{array}{c}\text { Run } \\
\text { no. }\end{array}$} & \multicolumn{3}{|c|}{ Network formers } & \multicolumn{8}{|c|}{ Network modifiers } \\
\hline & & $\mathrm{a}(\mathrm{NaAl})$ & $\mathrm{a}(\mathrm{KAl})$ & $\mathrm{a}(\mathrm{Si})$ & $\mathrm{a}(\mathrm{Mg})$ & $\mathrm{a}(\mathrm{Al})$ & $a(P)$ & $\mathrm{a}(\mathrm{Ca})$ & $\mathrm{a}(\mathrm{Ti})$ & $\mathrm{a}(\mathrm{Cr})$ & $\mathrm{a}(\mathrm{Mn})$ & $\mathrm{a}(\mathrm{Fe})$ \\
\hline 834 & R17 & 0.0721 & 0.0022 & 0.9258 & 0.2074 & 0.3552 & 0.0005 & 0.2658 & 0.0195 & 0.00008 & 0.0023 & 0.1491 \\
\hline 839 & R7 & 0.0621 & 0.0059 & 0.9320 & 0.2640 & 0.2945 & 0.0005 & 0.2755 & 0.0106 & 0.00071 & 0.0028 & 0.1513 \\
\hline 839 & R17 & 0.0366 & 0.0040 & 0.9595 & 0.2211 & 0.3270 & 0.0005 & 0.2497 & 0.0110 & 0.00041 & 0.0024 & 0.1880 \\
\hline $839 \mathrm{Al}$ & R5 & 0.0597 & 0.0058 & 0.9345 & 0.3758 & 0.2872 & 0.0008 & 0.2196 & 0.0088 & 0.00227 & 0.0030 & 0.1026 \\
\hline $839 \mathrm{Al}$ & R7 & 0.0616 & 0.0070 & 0.9313 & 0.2786 & 0.3021 & 0.0006 & 0.2790 & 0.0136 & 0.00080 & 0.0033 & 0.1219 \\
\hline $839 \mathrm{Al}$ & R10 & 0.0266 & 0.0037 & 0.9696 & 0.2816 & 0.3772 & 0.0003 & 0.2577 & 0.0094 & 0.00113 & 0.0025 & 0.0701 \\
\hline $839 \mathrm{Al}$ & R11 & 0.0229 & 0.0022 & 0.9750 & 0.3897 & 0.3005 & 0.0008 & 0.2045 & 0.0077 & 0.00203 & 0.0025 & 0.0923 \\
\hline $839 \mathrm{Mg}$ & R5 & 0.0605 & 0.0061 & 0.9334 & 0.3931 & 0.2654 & 0.0009 & 0.2507 & 0.0097 & 0.00303 & 0.0029 & 0.0743 \\
\hline $839 \mathrm{Mg}$ & R6 & 0.0565 & 0.0048 & 0.9387 & 0.3706 & 0.2842 & 0.0005 & 0.2128 & 0.0083 & 0.00133 & 0.0030 & 0.1193 \\
\hline $839 \mathrm{Mg}$ & R7 & 0.0616 & 0.0059 & 0.9325 & 0.2505 & 0.2934 & 0.0006 & 0.2909 & 0.0109 & NA & 0.0025 & 0.1512 \\
\hline $839 \mathrm{Mg}$ & $\mathrm{R} 15$ & 0.0366 & 0.0052 & 0.9582 & 0.3393 & 0.2982 & 0.0008 & 0.2660 & 0.0102 & 0.00178 & 0.0029 & 0.0807 \\
\hline $839 \mathrm{Mg}$ & R16 & 0.0500 & 0.0064 & 0.9436 & 0.2254 & 0.3544 & 0.0013 & 0.2767 & 0.0117 & 0.00060 & 0.0026 & 0.1272 \\
\hline
\end{tabular}

Notes: $\mathrm{a}(\mathrm{X})=$ activity of melt component $\mathrm{X}$ calculated from Table 5 according to the two-lattice model of Nielsen and Drake (1979), which assumes no mixing between lattices and ideal mixing within lattices. $\mathrm{NA}=$ not analyzed.

not analyzed and one composition at $1153^{\circ} \mathrm{C}$ (Run 17, Sample 839) were excluded from the calculations. (This last point was excluded from the regression because of the above-mentioned kinetic effect on plagioclase, the additional complication of higher $\mathrm{Fe}^{3+}$ in the spinel, and the poor precision of the $\mathrm{Cr}$ analysis of the glass.)

The variation of the equilibrium constant $\left(\mathrm{K}_{1}\right)$ with temperature (Fig. 7) suggests that it is possible to estimate liquid $\mathrm{Cr}^{3+} \#$ if spinel composition, temperature, and $\mathrm{fO}_{2}$ are known by means of the following equation:

$$
\mathrm{K}_{1} \cdot \mathrm{a}(\mathrm{Mg}-\mathrm{chr}) / \mathrm{a}(\mathrm{sp})=\mathrm{a}\left(\mathrm{Cr}_{2} \mathrm{O}_{3}\right) / \mathrm{a}\left(\mathrm{Al}_{2} \mathrm{O}_{3}\right) .
$$

Note that $\mathrm{K}_{1}$ is primarily dependent on temperature, but the $\mathrm{Cr}_{2} \mathrm{O}_{3}$ (liq), and therefore $\mathrm{a}\left(\mathrm{Cr}_{2} \mathrm{O}_{3}\right)$, is dependent on $\mathrm{fO}_{2}$ (Roeder and Reynolds, 1991). Hence, Equation 2 is constrained by temperature, $\mathrm{fO}_{2}$, and spinel composition. Details of the calculation are given in the Appendix. (Eq. 2 should be equally useful in predicting spinel compositions from a given liquid composition.)
To test the usefulness of this expression for calculating the $\mathrm{Cr}^{3+} \# \mathrm{~s}$ of the melt, we applied it to the experimental data of Roeder and Reynolds (1991). Figure 8 shows the $\mathrm{Cr}^{3+} \#$ calculated from their spinel compositions on the $x$-axis and the $\mathrm{Cr}^{3+} \# \mathrm{~s}$ of the coexisting glass compositions on the $y$-axis. The $\mathrm{Cr}^{3+} \#$ s derived from their analyzed glasses and our calculated values are in good agreement, even for their wider $\mathrm{fO}_{2}$, temperature, and compositional range. Thus, the expression predicts $\mathrm{Cr} \#$ in melt from $\mathrm{Cr} \#$ in spinel when temperature and $\mathrm{fO}_{2}$ are known.

\section{CONCLUSIONS}

Even though our Sample 839 has clearly accumulated olivine and spinel, the initial parent composition must have had the same or higher Mg\# based on both the spinel and olivine cores. Its hybrid character is shown by the Fe-rich rims on spinels and the single glass analysis (Allan, this volume), which shows a host liquid with higher $\mathrm{Al}$ and $\mathrm{Si}$ and lower $\mathrm{Mg}$ than the equilibrium composition predicted from the phenocryst compositions. Such higher Al liquids may be expected to 


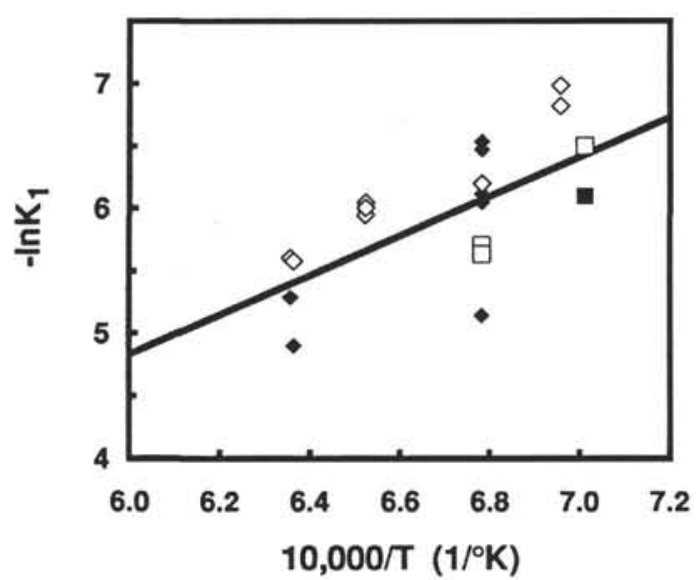

Figure 7. Values of $-\ln K_{1}$ calculated for each of the experimental spinel-average glass pairs. Symbols are the same as in Figure 4. The line is a linear regression calculated for the points shown. Values of $K_{1}$ were used to produce Figure 8 from the temperature and spinel compositions reported by Roeder and Reynolds (1991)

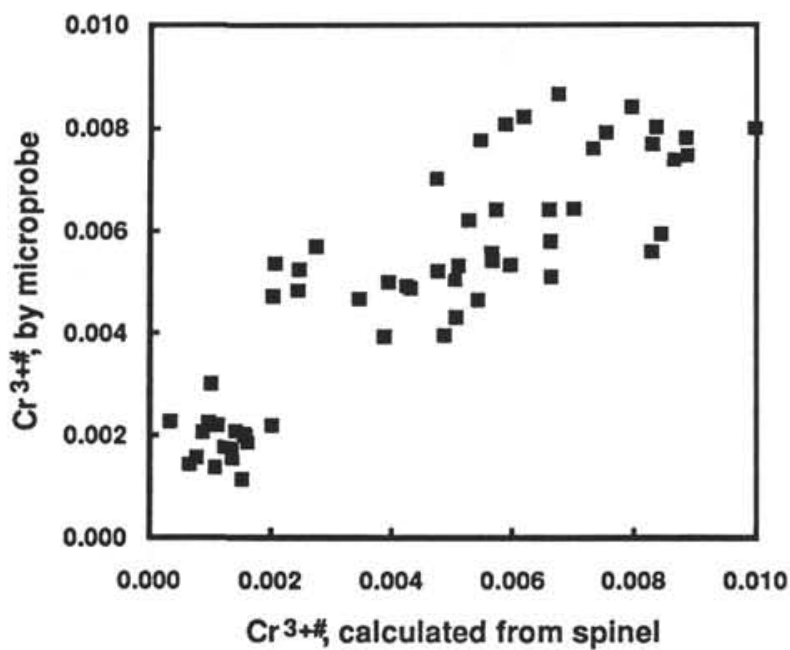

Figure 8. $\mathrm{Cr}^{3+} \#$ on the $y$-axis is for the glass from microprobe data of Roeder and Reynolds (1991) and calculated as described in discussion section. $\mathrm{Cr}^{3+} \#$ on the $x$-axis calculated from Roeder and Reynolds (1991) spinels and our reaction constant, $\mathrm{K}_{1}$.

be in equilibrium with lower $\mathrm{Cr} \#$ spinels than the natural spinel phenocrysts, which is what we observed. Therefore, based on our experiments and the equations derived by us and Allan (this volume), the following conclusions may be reached:

1. Comparison of the Cr\#s and $\mathrm{Mg \# s}$ of the natural spinels and our synthesized spinels indicates that crystallization must have taken place at high temperatures $\left(1200^{\circ}-1250^{\circ} \mathrm{C}\right.$, most likely closer to $\left.1250^{\circ} \mathrm{C}\right)$.

2. Oxygen fugacity must have been near the QFM buffer because Cr-spinel probably would not have formed at lower $\mathrm{fO}_{2}$ and the $\mathrm{Cr}$ content of spinel at higher $\mathrm{fO}_{2}$ would have been lower than observed in the phenocrysts. Furthermore, $\mathrm{Al}$ must have some effect on the stabilization of $\mathrm{Cr}$-spinel because the only run containing spinel at the lower $\mathrm{fO}_{2}$ was the one doped with $\mathrm{Al}_{2} \mathrm{O}_{3}$.

3. Zoning of the Mg\#s $(0.50-0.75)$ of the natural spinel probably results from changes in the melt $\mathrm{Mg} \# \mathrm{~s}$. However, the $\mathrm{Cr} \#$ in these spinels does not vary and, because $\mathrm{Mg} \#$ and $\mathrm{Cr} \#$ should both decrease as equilibrium crystallization occurs, it must reflect the effect of disequilibrium (Scowen et al., 1991). Based on our experiments and previous studies, decoupling these elements even under open-system processes is difficult to envision.

\section{ACKNOWLEDGMENTS}

We would like to thank S. Delong for providing the $\mathrm{Cr}$ glass standards. Research was funded by ODP Grant No. 20563 to M.R.F. Helpful discussions with P. Roeder, J. Hawkins, R. Nielsen, and members of the Leg 135 shipboard party who freely contributed their insight are also gratefully acknowledged. In addition, our thanks to M. Clynne and R. Sack for very useful and detailed reviews.

\section{REFERENCES}

Allan, J.F., 1992. Cr-spinel as a petrogenetic indicator: deducing magma composition from spinels in highly altered basalts from the Japan Sea, Sites 794 and 797. In Tamaki, K., Suyehiro, K., Allan, J., McWilliams, M., et al., Proc. ODP, Sci. Results, $127 / 128$ (Pt. 2): College Station, TX (Ocean Drilling Program), 837-847.

Allan, J.F., Sack, R.O., and Batiza, R., 1988. Cr-rich spinels as petrogenetic indicators: MORB-type lavas from the Lamont seamount chain, eastern Pacific. Am. Mineral., 73:741-753.

Anderson, D.J., Bishop, F.C., and Lindsley, D.H., 1991. Internally consistent solution models for the Fe-Mg-Mg-Ti oxides: Fe-Mg-Ti oxides and olivine. Am. Mineral., 76:427-444.

Ballhaus, C., Berry, R.F., and Green, D.H., 1991. High pressure experimental calibration of the olivine-orthopyroxene-spinel oxygen geobarometer: implications for the oxidation state of the upper mantle. Contrib. Mineral. Petrol., 107:27-40.

Barnes, S.J., 1986. The distribution of chromium among orthopyroxene, spinel and silicate liquid at atmospheric pressure. Geochim. Cosmochim. Acta. 50:1889-1909.

Barsdell, M., 1988. Petrology and petrogenesis of clinopyroxene-rich tholeitic lavas, Merelava Volcano, Vanuatu. J. Petrol., 29:927-964.

Bottinga, Y., and Weill, D.F., 1972. The viscosity of magmatic silicate liquids: a model for calculation. Am. J. Sci., 272:438-475.

Dick, H.J.B., and Bullen, T., 1984. Chromian spinel as a petrogenetic indicator in abyssal and alpine-type peridotites and spatially associated lavas. Contrib. Mineral. Petrol., 86:54-76.

Fisk, M.R., and Bence, A.E., 1980. Experimental crystallization of chrome spinel in FAMOUS basalt 527-1-1. Earth Planet. Sci. Lett., 48:111-123.

Grove, T.L., 1981. Use of FePt alloys to eliminate the iron loss problem in 1 atmosphere gas mixing experiments: theoretical and practical considerations. Contrib. Mineral. Petrol., 78:298-304.

Hill, R.H., and Roeder, P.L., 1974. The crystallization of spinel from basaltic liquid as a function of oxygen fugacity. J. Geol., 82:709-722.

Irvine, T.N., 1965. Chromium spinel as a petrogenetic indicator. Part 1: Theory. Can. J. Earth Sci., 2:648-672.

, 1967. Chromium spinel as a petrogenetic indicator. Part 2: Petrological applications. Can. J. Earth Sci., 4:71-103.

Jarosewich, E., Nelen, J.A., and Norberg, J.A., 1980. Reference samples for electron microprobe analysis. Geostand. Newslett., 4:43-47.

Lofgren, G.E., and Donaldson, C.H., 1975. Phase relations and nonequilibrium crystallization of ocean ridge tholeiite from the Nazca Plate. Eos, 56:468.

Nielsen, R.L., and Drake, M.J., 1979. Pyroxene-melt equilibria. Geochim. Cosmochim. Acta, 42:817-831.

Parson, L., Hawkins, J., Allan, J., et al., 1992. Proc. ODP, Init. Repts., 135: College Station, TX (Ocean Drilling Program).

Roeder, P.L., Campbell, I.H., and Jamieson, H.E., 1979. A re-evaluation of the olivine-spinel geothermometer. Contrib. Mineral. Petrol., 68:325-334.

Roeder, P.L., and Reynolds, I., 1991. Crystallization of chromite and chromium solubility in basaltic liquid. J. Petrol., 32:909-934.

Sack, R.O., 1982. Spinels as petrogenetic indicators: activity-composition relations at low pressures. Contrib. Mineral. Petrol., 79:169-186.

\footnotetext{
Abbreviations for names of organizations and publication titles in ODP reference lists follow the style given in Chemical Abstracts Service Source Index (published by American Chemical Society).
} 
Sack, R.O., Carmichael, I.S.E., Rivers, M.L., and Ghiorso, M.S., 1980. Ferricferrous equilibria in natural silicate liquids at 1 bar. Contrib. Mineral. Petrol., 75:369-376.

Sack, R.O., and Ghiorso, M.S., 1991. Chromian spinels as petrogenetic indicators: thermodynamics and petrological applications. Am. Mineral., 76:827-847.

Scowen, P.A., Roeder, P.L., and Helz, R., 1991. Reequilibration of chromite within Kileauea Iki lava lake, Hawaii. Contrib. Mineral. Petrol., 107:8-20.
Sigurdsson, H., and Schilling, J.-G., 1976. Spinels in Mid-Atlantic Ridge basalts: chemistry and occurrence. Earth Planet. Sci. Lett., 29:7-20.

Thy, P., 1983. Spinel minerals in transitional and alkali basaltic glasses from Iceland. Contrib. Mineral. Petrol., 83:141-149.

Date of initial receipt: 6 August 1992

Date of acceptance: 14 May 1993

Ms 135SR-131

\section{APPENDIX}

\section{Procedure for Calculating - $\ln \mathrm{K}_{1}$}

1. Mole fractions of elements in spinel with minor components ( $\mathrm{Mn}, \mathrm{Ni}, \mathrm{Zn}, \mathrm{V})$ ignored.

2. Sack and Ghiorso (1991) parameters for spinel composition.

3. Sack and Ghiorso (1991) spinel activity calculation.

4. Cation mole fractions for coexisting glass.

5. Activities of elements in the glass by the Nielsen and Drake (1979) two-lattice melt model.

6. Activity of $\mathrm{Cr}^{3+}$ from $\mathrm{f}\left(\mathrm{O}_{2}\right)$ and two-lattice activity of $\mathrm{Cr}$ (Roeder and Reynolds, 1991).

7. $-\ln \mathrm{K}_{1}$ for that mineral-melt pair from Equation 1 using the calculated activities.

An example using data from the tables for Sample 834, Run 17:
(Calculated from values in Table 4.)
2. $\begin{array}{lllll}\mathrm{X} 2 & \mathrm{X} 3 & \mathrm{X} 4 & \mathrm{X} 5 & \text { Temperature }(\mathrm{K})\end{array}$

$\begin{array}{lllll}0.718 & 0.145 & 0.012 & 0.158 & 1426\end{array}$

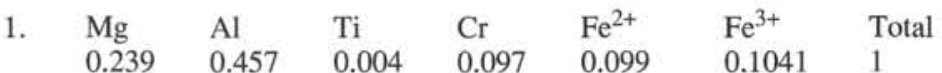
where $\mathrm{X} 2=\mathrm{Mg} \bullet 3$,
$\mathrm{X} 3=\mathrm{Cr} \cdot 1.5$,
$\mathrm{X} 4=\mathrm{Ti} \cdot 3$, and
$\mathrm{X} 5=(2 / 3-\mathrm{Al}-\mathrm{Cr}-2 \cdot \mathrm{Ti}) \cdot 1.5$.
3. $\mathrm{a}(\mathrm{hc}) \quad \mathrm{a}(\mathrm{sp}) \quad \mathrm{a}($ usp) $\quad \mathrm{a}(\mathrm{mt}) \quad \mathrm{a}(\mathrm{Mg}-\mathrm{Ti}) \quad \mathrm{a}(\mathrm{Mg}-\mathrm{Fe}) \quad \mathrm{a}(\mathrm{chr}) \quad \mathrm{a}(\mathrm{Mg}-\mathrm{chr})$

$\begin{array}{llllllll}0.313 & 0.396 & 0.021 & 0.128 & 0.018 & 0.071 & 0.037 & 0.030\end{array}$

$\begin{array}{llllllllllll}\text { 4. } & \mathrm{Na} & \mathrm{Mg} & \mathrm{Al} & \mathrm{Si} & \mathrm{P} & \mathrm{K} & \mathrm{Ca} & \mathrm{Ti} & \mathrm{Cr} & \mathrm{Mn} & \mathrm{Fe} \\ & 0.036 & 0.095 & 0.2 & 0.466 & 0.0002 & 0.0011 & 0.122 & 0.009 & 0.00005 & 0.001 & 0.068 \\ & & & & & & & & & & & \\ \text { 5. } & \mathrm{a}(\mathrm{NaAl}) & \mathrm{a}(\mathrm{KAl}) & \mathrm{a}(\mathrm{Si}) & \mathrm{a}(\mathrm{Mg}) & \mathrm{a}(\mathrm{Al}) & \mathrm{a}(\mathrm{P}) & \mathrm{a}(\mathrm{Ca}) & \mathrm{a}(\mathrm{Ti}) & \mathrm{a}(\mathrm{Cr}) & \mathrm{a}(\mathrm{Mn}) & \mathrm{a}(\mathrm{Fe}) \\ & 0.072 & 0.002 & 0.926 & 0.207 & 0.355 & 0.0005 & 0.266 & 0.02 & 0.00008 & 0.002 & 0.149\end{array}$

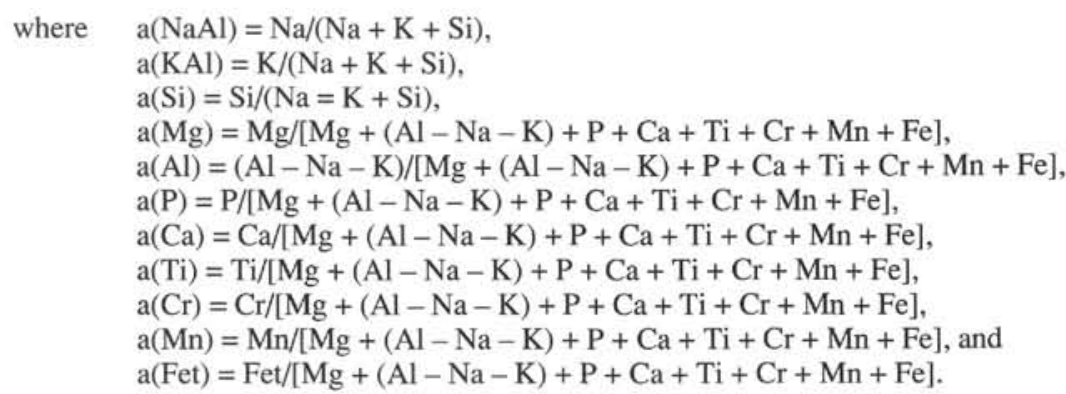
6. $\quad \log \mathrm{f}\left(\mathrm{O}_{2}\right)$
$-7.05 \quad(\mathrm{QFM}+2)$
$\mathrm{Cr}^{2+} / \mathrm{Cr}^{3+} \mathrm{liq}$
0.366
$\mathrm{a}\left(\mathrm{Cr}^{3+}\right)$
0.00006

where $\mathrm{Cr}^{2+} / \mathrm{Cr}^{3+}=10^{\left[\left(-0.28 \cdot \log \mathrm{fO}_{2}\right)-2.41\right]}$ and

$\mathrm{a}\left(\mathrm{Cr}^{3+}\right)=\mathrm{a}(\mathrm{Cr}) /\left[\left(\mathrm{Cr}^{2+} / \mathrm{Cr}^{3+}\right)+1\right]$.

7. $-\ln \mathrm{K}_{1}$

6.099

where $\mathrm{K}_{1}=-\ln \left[\mathrm{a}(\mathrm{sp}) \cdot \mathrm{XCr}^{3+}\right] /[\mathrm{a}(\mathrm{Mg}-\mathrm{chr}) \cdot \mathrm{a}(\mathrm{Al})]$. 